\title{
Courtyard Sound Field Characteristics by Bell Sounds in Han Chinese Buddhist Temples
}

\author{
Dongxu Zhang ${ }^{1, *}$, Chunxiao Kong ${ }^{1}$, Mei Zhang ${ }^{2}$ and Qi Meng ${ }^{3, *}$ \\ 1 JangHo Architecture College, Northeastern University, Shenyang 110819, China; 15204009851@163.com \\ 2 School of East Asia Studies, University of Sheffield, Sheffield S10 2TD, UK; m.zhang@sheffield.ac.uk \\ 3 Key Laboratory of Cold Region Urban and Rural Human Settlement Environment Science and Technology, \\ Ministry of Industry and Information Technology, School of Architecture, Harbin Institute of Technology, \\ 66 West Dazhi Street, Nan Gang District, Harbin 150001, China \\ * $\quad$ Correspondence: dongxu75@163.com (D.Z.); mengq@hit.edu.cn (Q.M.)
}

Received: 4 January 2020; Accepted: 12 February 2020; Published: 14 February 2020

\begin{abstract}
The acoustic environments of Han Chinese Buddhist temples have long played an important role in the development of Buddhism. This study explored the effects of layouts and spatial elements of Han Chinese Buddhist temples on courtyard sound fields. First, sound fields of three traditional Han Chinese courtyards were measured, and results were compared with sound field simulations to determine the appropriate acoustic and software parameter setting for ancient building materials in the context of sound field simulation. Next, a sound field model for standard forms of Han Chinese Buddhist temples was built and analysed. Results indicate that in traditional Buddhist temples, spatial elements-such as the height and sound absorption coefficient of temple courtyard walls, position of courtyard partition walls, and the position and height of bell towers-could significantly affect the sound pressure level (SPL), reverberation time (RT), and musical clarity $\left(\mathrm{C}_{80}\right)$ of each courtyard. However, enclosure materials, such as those used in roofs, on the ground, and in windows of Han Chinese Buddhist temples, had relatively small effects on temple courtyard sound fields.
\end{abstract}

Keywords: Chinese Buddhist temple; spatial elements; courtyard sound fields; partition walls; bell tower; interface materials

\section{Introduction}

Han Chinese Buddhism has a history of more than 2000 years in China. During this time, Han Chinese Buddhist temples' courtyards have provided monks and believers with a pleasant environment for religious practice; furthermore, they have also served as an important public activity space in ancient China [1]. Throughout history, good acoustic environments of temples have played an important role in the development and spread of Buddhism. The bell ringing and chanting performed in temples form a unique religious sound field that makes a deep impression on visitors and helps believers reproduce the wonderful world of Buddha in their hearts, while participating in religious activities and co-creating a religious artistic conception of Buddhism with visual environments [2]. However, Han Chinese Buddhist temples' sound fields have not been scientifically analysed, and their acoustic assessment is currently lacking. Extant research falls into the following categories. Some have focused on courtyard spaces of various types of temples around the world. Wang [3] analysed the developmental history of Han Chinese Buddhist temple courtyard layouts, and Liu [1] investigated the spatial composition of their traditional courtyards. Hatem Odah et al. explored the courtyard of the Hatshepsut Temple in Egypt [4], and McGovern analysed a Japanese Buddhist garden, which is part of a Zen temple complex in Kyoto City, from the perspectives of philosophical perceptions and religious ideals [5].

Studies have been conducted on various sound fields, such as those in gardens. Davis et al. measured the number of random incidences of sound absorption in vertical garden modules [6]. 
Hedfors introduced the concept of a sonotope and discussed strategies for achieving sonic authenticity or a progressive acoustic design in historical gardens [7]; Fowler investigated the synthesis of landscape and soundscape elements in Japanese gardens, considering sound a design parameter [8,9]. Wong et al. studied the acoustic evaluation of vertical greenery systems for building walls and determined the sound absorption coefficient of this system [10]. Gozalo et al. found that places in green spaces where people frequently undertake walking and relaxation activities have the lowest sound levels [11]. Studies on sound propagation through vegetation show that significant noise reduction may be achieved for a predominantly high frequency source if the existing ground cover is acoustically hard [12]. Heijden et al. studied the possible influence of vegetation on acoustically relevant soil parameters [13], while Londhe et al. measured the acoustic absorption coefficients of grass and artificial turf surfaces for normal incidences from a sound source [14].

For sound fields of traditional indoor and outdoor performance spaces, Chourmouziadou and Kang investigated the evolution of ancient Greek and Roman outdoor performance spaces, believing that changes in materials and theatre design could generally improve acoustic properties [15]. Using experimental data, Beranek and Hidaka determined absorption coefficients for wood, plaster, and concrete interior surfaces of various thicknesses and densities in concert and opera halls [16]. Vassilantonopoulos and Mourjopoulos analysed acoustic properties for ancient Greek and Roman open-air theatres via computer-aided prediction and auralisation; they explored famous buildings of antiquity using virtual acoustics to reconstruct the ritual and public buildings of the ancient Greek world $[17,18]$. Farina discovered correlations between physical parameters and subjective evaluations in Italian theatres and halls [19]. Shtrepi et al. analysed a variable-acoustic concert hall and found that listeners in a simulated performance space could perceive the presence of different acoustic scattering properties, and this perception was related to the distance from the diffusive surface and to their geometric modelling [20]. Bo et al. presented a study on the accuracy of predicted acoustical parameters in the Syracuse open-air theatre, with experiments and simulations [21]. Kamisiński dealt with the problem of acoustic correction in historic opera theatres [22].

For sound fields of religious spaces, Martellotta and Cirillo analysed the influence of different types of pews on acoustical characteristics of churches [23]. Alonso and Martellotta's research stated that freely hung textiles may absorb more sound than if the same panel was hung flush to a wall, particularly at higher frequencies; they also showed that the effect of textiles on church acoustics is more evident at medium frequencies than at lower frequencies [24]. Through software simulation, Berardi studied the acoustics of 25 box-shaped churches; he believed that length-to-width ratios had a significant influence on $\mathrm{C}_{80}$ and centre time values [25]. Berardi et al. made a comparative analysis of acoustic energy models for churches using measurements from 24 Italian churches that differed in style, typology, and location [26]. Navarro et al. stated that acoustics in churches are fundamentally associated with the way these churches are covered [27]. Cirillo and Martellotta's research showed that churches with a vaulted nave have considerably longer RT values, while wooden ceilings with painted canvases caused significant RT reduction, particularly at medium and low frequencies [28]. Sant'Ana and Zannin conducted an acoustic survey in a church in Brazil that has a modern architectural style in order to assess the acoustic quality of the nave [29]. Chu and Mak took acoustical measurements based on impulse responses in two churches in Hong Kong, and their analysis was concentrated on RT, early decay time (EDT), $\mathrm{C}_{80}$, early-to-late ratio, and integrated decay [30]. Kosala and Engel investigated and analysed the acoustic properties of Polish Roman Catholic churches, and the index they proposed can be used in simulation investigations and to forecast acoustic quality changes [31]. Brink et al. presented a study to analyse church bell noises and sleep disturbances of nearby residents [32]. Soeta et al. found that in Japanese churches, changes in the direction could improve the intelligibility of speech. By contrast, source location had relatively little effect on acoustic parameter values [33]. Girón et al. summarised principal contributions to the acoustics of ancient occidental Christian churches in recent decades [34]. Manohare et al. analysed the sound field characteristics of a large hollow stupa in an Indian Buddhist temple in Nagpur by means of 
an in situ measurement and simulation, and investigated the effects of these characteristics on religious activities [35]. Orfali and Ahnert discussed the current sound systems in mosques, and introduced the effect of these systems on the mosques' applicable sound parameter [36]. These different religions adopted different worship rituals and architectural space; however, all these studies have shown that the appropriate sound field is important for creating a religious atmosphere, and is thus significantly related to our study.

Although many previous results are related to sound fields of gardens, traditional outdoor performance spaces, and interior sound fields of churches, these research subjects are significantly different from the courtyards of Han Chinese Buddhist temples in terms of courtyard layout, sound source characteristics, and the arrangement of sound absorbers. Therefore, from a spatial perspective, research on Han Chinese Buddhist temples' courtyard sound fields is still lacking.

This study focuses on courtyard sound fields of Han Chinese Buddhist temples and employs acoustic software (ODEON 13.02, Copenhagen, Denmark) to simulate typical courtyard sound fields, with the aim of revealing the effects exerted by temple layouts, various spatial elements, and sound sources. First, sound fields of three traditional courtyards are measured. Then, parameters of the measured and simulated sound fields are compared to determine the appropriate acoustic parameters (used in the simulation) for traditional courtyard interface materials. Next, a sound field model for standard temple forms is established, and changes in courtyard sound fields are analysed after changing the model or material parameters; this reveals the impact mechanisms of each spatial element on courtyard sound fields. The findings of this study are useful for understanding the courtyard sound fields of Han Chinese Buddhist temples. Moreover, the study can serve as a reference for understanding sound fields of other types of traditional Chinese gardens. It also offers guidance for protecting or restoring acoustic environments of Han Chinese Buddhist temples and similar ancient buildings.

\section{Research Methods}

\subsection{The Spatial Characteristics of Han Chinese Buddhist Temples}

Courtyards have developed into a relatively fixed spatial form through the long developmental history of Chinese Buddhist temples, because of traditional Chinese ritual systems and Buddhist cultures. Except for a minority of Buddhist temples, which adopted a freestyle layout, mainly due to their locations in mountains and restrictions imposed by the surrounding natural environment, most Han Chinese Buddhist temple courtyards have an axisymmetric and multi-courtyard layout. These courtyards have the following spatial layout characteristics: (1) a regular, symmetrical layout that generally consists of three to six courtyards that are enclosed by walls or wing-rooms; (2) a two-storey bell tower on one side of the first courtyard, with a drum tower opposite it on the other side; (3) the absence of partition walls between most courtyards; and (4) the use of a hard stone material for most ground paving, with the sporadic presence of greenery or bare soil.

\subsection{An Acoustic Model of Han Chinese Buddhist Temples}

The outdoor courtyard spaces of Han Chinese Buddhist temples were simulated in this study using acoustic software (Odeon). Based on geometrical acoustics, the software uses a hybrid approach that combines both the image source and the ray-tracing method in conjunction with the secondary source method to perform computer-aided sound field simulation on the absorption, scattering, and diffraction of sound waves. Aside from enclosed buildings, the software is applicable to open plazas and semi-enclosed buildings as well.

The software calculation settings were set to the most accurate mode: 'precision'. Quick and global estimate functions were used to estimate the reverberation time of the acoustic models. The computation results, including multiple acoustic parameters, such as EDT, $\mathrm{T}_{30}$ (reverberation time extrapolated from the time required for sound to decay by $30 \mathrm{~dB}$, from $-5 \mathrm{~dB}$ to $-35 \mathrm{~dB}$ ), $\mathrm{C}_{80}$, and SPL, provided comprehensive reference data for acoustic analysis [37,38]. 
According to the basic layout proposed by Wang [3] for ancient Han Chinese Buddhist temples (Figure 1) and a field survey on temple typicality, this study established an acoustic model for standard forms of Han Chinese Buddhist temples (Figure 2). Geometric dimensions of the model were set by referring to the reported survey results of key Han Chinese Buddhist temples throughout China. In all, $70 \%$ of Buddhist temples are less than $100 \mathrm{~m}$ wide, $33 \%$ have a depth of $50 \mathrm{~m}$ to $100 \mathrm{~m}$, and $47 \%$ have a depth of $100 \mathrm{~m}$ to $200 \mathrm{~m}$ [39]. In this study, the model's temple width was set to $50 \mathrm{~m}$, depth was set to $150 \mathrm{~m}$, and there were four courtyards along the central axis. In the model, sound receivers were placed on a grid of $10 \mathrm{~m} \times 10 \mathrm{~m}$ cells in each courtyard; each receiver was situated $1.5 \mathrm{~m}$ above the ground and more than $3 \mathrm{~m}$ from the building boundary. Four sound receivers were placed in the first courtyard, wherein the bell tower and drum tower were located, and 15 were placed in the second. This second courtyard was the front courtyard of the Great Buddha Hall-the largest hall in the temple. Ten sound receivers were placed in each of the third and fourth courtyards. Sound receiver locations are illustrated in Figure 2, denoted by dots.

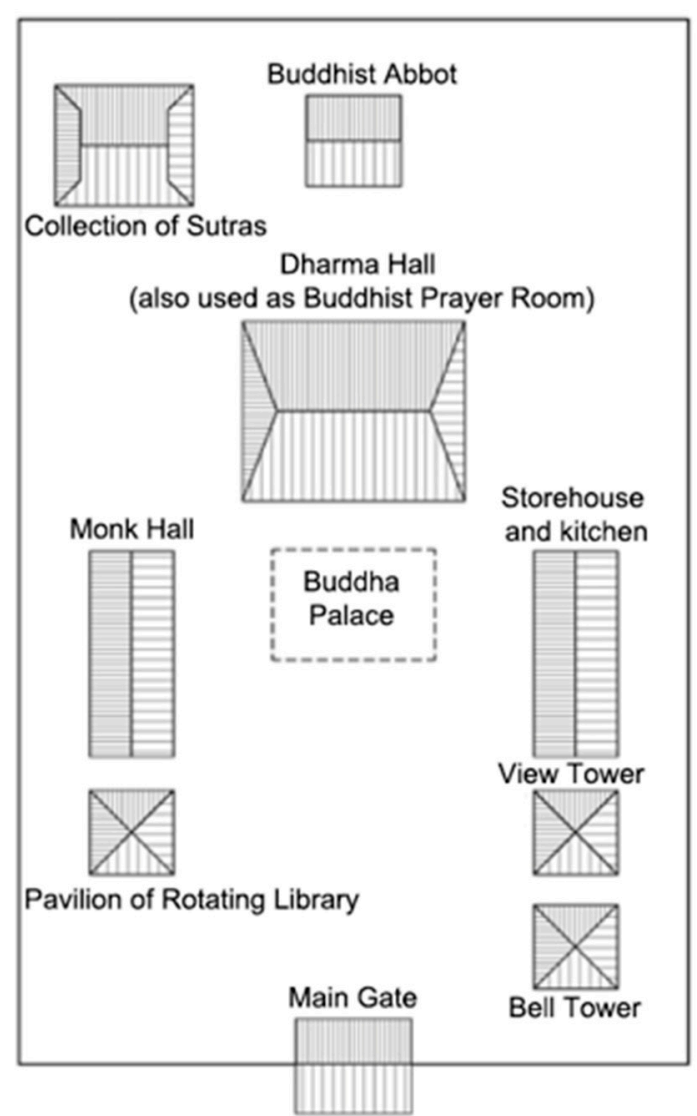

(a)

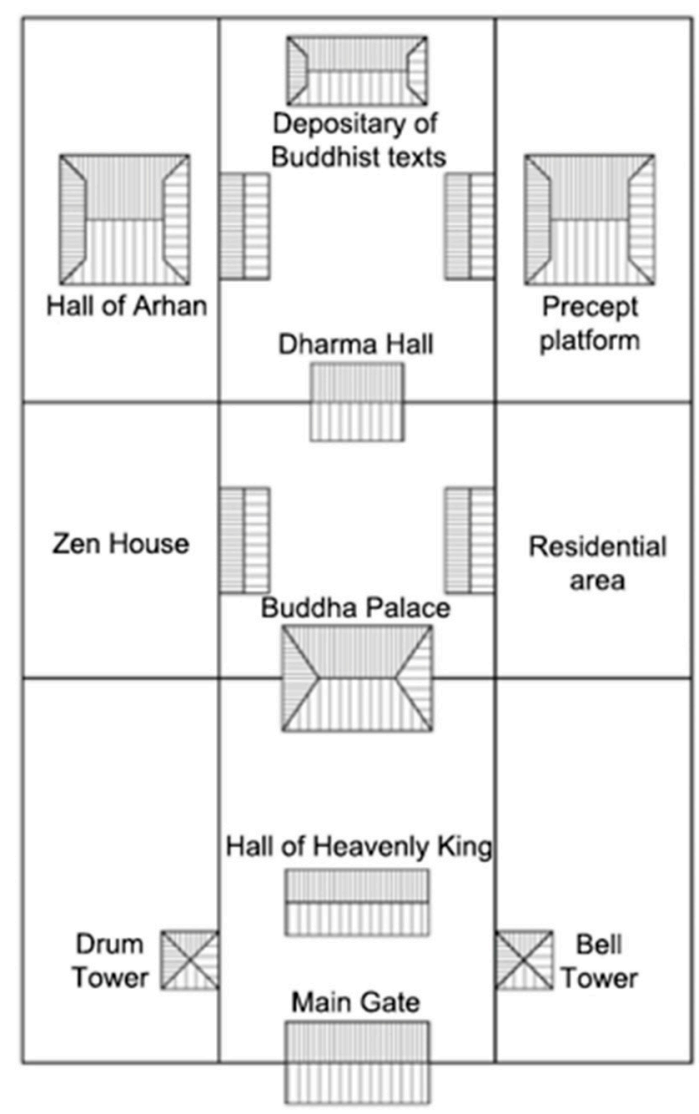

(b)

Figure 1. Layout of Buddhist temples in ancient China. (a) Layout during the Song dynasty. (b) Layout during the Qing dynasty.

Considering that Odeon software is typically used to simulate the sound field of indoor spaces, the sound field model of a semi-closed courtyard in a Chinese Buddhist temple in this study was placed in a cube larger than the courtyard (Figure 2); subsequently, sound absorption coefficients of this cube's surfaces at each frequency were set to 1 (the sound was completely absorbed). With this setting, the sound field of a semi-closed courtyard could be more accurately simulated.

For an acoustic parameter in a given courtyard, calculation results were averaged over all sound receivers, and different courtyard sound fields' averages were compared. A weighted sound pressure level (SPL(A)) was measured in place of SPL, since SPL(A) closely mimics the auditory characteristics 
of human ears. RT was measured as $\mathrm{T}_{30}$ and EDT, and comparison and analysis were performed on the average results at typical middle frequencies (which are averages of values on the bands of $500 \mathrm{~Hz}$ and $1000 \mathrm{~Hz}$, denoted in this paper by the subscript " $\mathrm{m}$ ").

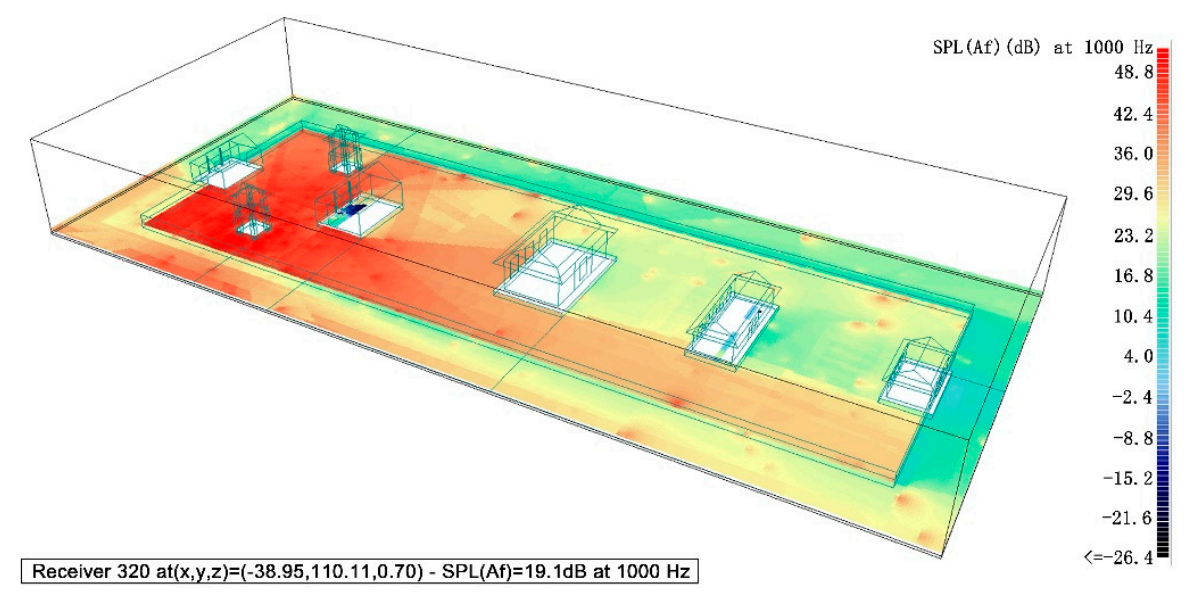

Receiver 320 at $(x, y, z)=(-38.95,110.11,0.70)-S P L(A f)=19.1 \mathrm{~dB}$ at $1000 \mathrm{~Hz}$

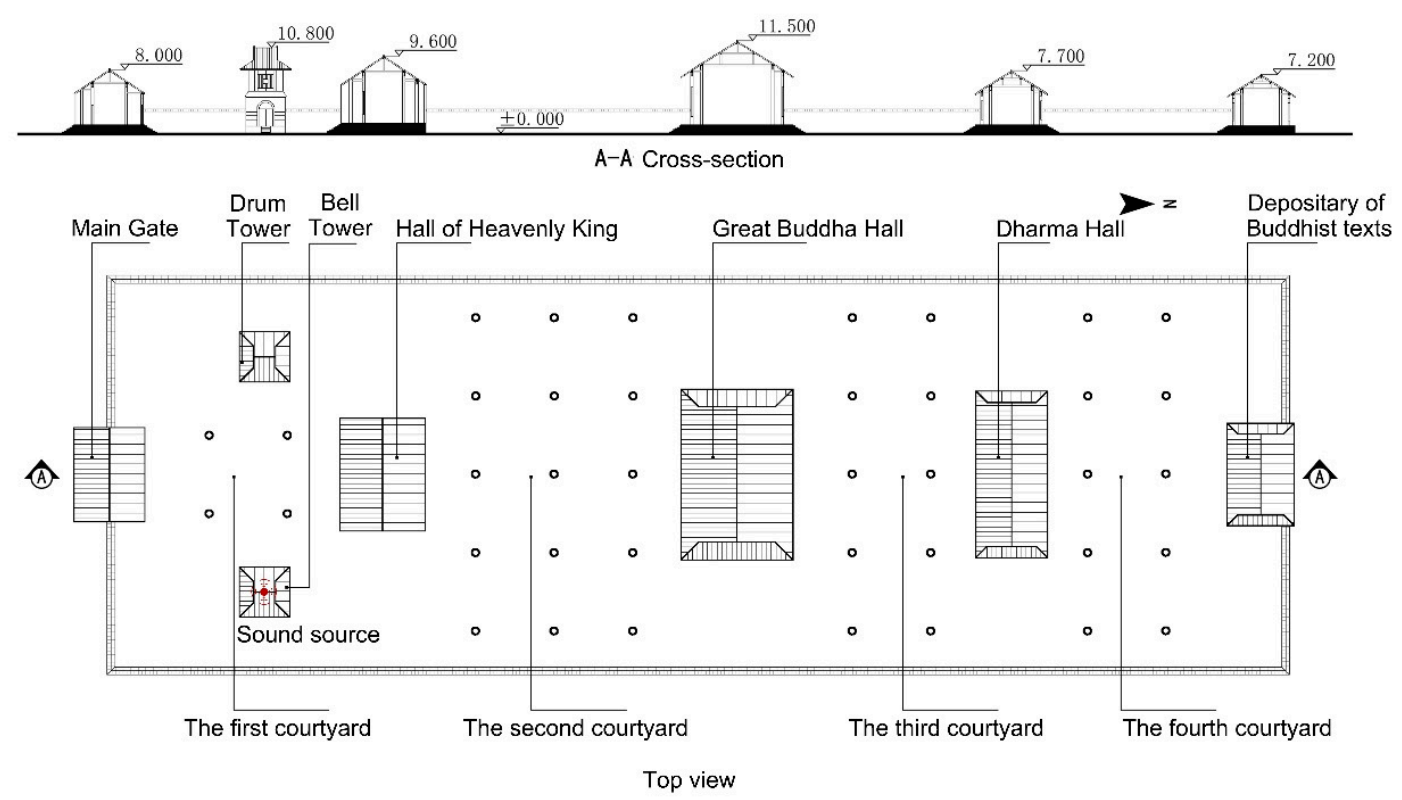

Figure 2. Acoustic model diagram, top view, and cross-sectional view of the Buddhist temple (the dots in the courtyard plane represent the positions of sound receivers).

In addition, three other acoustic parameters were included as references to enable the comparison of temple sound fields: $\mathrm{C}_{80}$ and the interaural cross-correlation coefficient (IACC). $\mathrm{C}_{80}$ describes musical clarity, which is defined as the logarithmic ratio of early-to-late sound energy, where "early" refers to sound arriving in the first $80 \mathrm{~ms}$, and "late" refers to sound arriving after this period. Generally, the shorter the RT, the bigger the $\mathrm{C}_{80}$ and the greater the musical clarity. $\mathrm{C}_{80}$ is usually measured using the average of two frequency bands centred at $500 \mathrm{~Hz}$ and $1000 \mathrm{~Hz}$, which allows the listener to feel whether the music is clear or the reverberation time is too long. IACC is a measure of the difference in sound signals received by a person's ears, which can, to a certain extent, evaluate the spatial sense of sound. IACC is usually measured using signals that are received at various locations within $80 \mathrm{~ms}$ after a direct sound and are averaged across the frequency bands centred on $500 \mathrm{~Hz}$, $1000 \mathrm{~Hz}$, and $2000 \mathrm{~Hz}$. Research results for the sound quality of several concert halls show that the value of $\left(1-\mathrm{IACC}_{\mathrm{E} 3}\right)$ is consistent with the audience's subjective evaluation; therefore, it is a reference 
parameter for evaluating sound quality in concert halls [40]. Table 1 shows just-noticeable differences (JND) for each acoustic parameter [41-44].

Table 1. JND for objective parameters.

\begin{tabular}{|c|c|c|c|c|c|}
\hline Parameter & $\begin{array}{c}G \\
(0.5-1 \mathrm{kHz})\end{array}$ & $\begin{array}{c}\mathrm{RT} \\
(0.5-1 \mathrm{kHz})\end{array}$ & $\begin{array}{c}\text { EDT } \\
(0.5-1 \mathrm{kHz})\end{array}$ & $\begin{array}{c}\mathrm{C}_{80} \\
(0.5-1 \mathrm{kHz})\end{array}$ & $\begin{array}{c}\text { IACC E3 }_{\text {E }} \\
(0.5-2 \mathrm{kHz})\end{array}$ \\
\hline JND & $1 \mathrm{~dB}$ & $5 \%$ & $5 \%$ & $1 \mathrm{~dB}$ & 0.075 \\
\hline
\end{tabular}

There are many kinds of sound sources in a temple [45], with courtyard sound fields varying greatly under different sound source conditions. In this study, the Chinese Buddhist temple's ringing bell, their most representative sound source, was selected. Other sound sources were not considered because these sounds were uncommon in the courtyard or had sound pressure levels that were too low. In the acoustic model, the sound source was set to the bell tower in the first courtyard, hanging $6 \mathrm{~m}$ above the ground. In the field survey, the bell sound was recorded at a distance of $1 \mathrm{~m}$ from the bell in Long Quan Temple's bell tower, which is located in the Qian Mountains in Liaoning province, China. The maximum instantaneous sound pressure levels were $86.3,70.5,90.9,83.4,77,67.5,60$, and $47.9 \mathrm{~dB}$ for eight frequency bands from $63 \mathrm{~Hz}$ to $8 \mathrm{kHz}$. Considering that the sound power level of the temple bell sound was a variable value, and only relative values from courtyard sound field simulation results were to be compared and analysed in this study, this set of SPL values was used to simulate a bell sound source instead of actual sound power level values.

\subsection{Acoustic Parameter Settings of Simulation Software}

First, there is a lack of references for the simulation of a courtyard sound field in Han Chinese Buddhist temple for this paper. Moreover, it is prohibited to fully and systematically measure the sound field in a Buddhist temple, as it is a sacred religious space in China. Therefore, in order to ensure the accuracy of the simulated temple sound fields in this research, courtyard sound field measurements were taken at Shenyang Imperial Palace, which has a similar architectural form to traditional Buddhist temples and uses comparable materials; notably, however, there are no Buddhist bell towers and drum towers in the courtyard of Shenyang Imperial Palace. Next, the sound absorption and scattering coefficients of traditional Chinese building materials were determined in the sound field simulation software by comparing simulated and measured data. Those coefficients will be used in the following simulation of a Buddhist courtyard sound field.

Shenyang Imperial Palace was built in 1625; in addition to being a World Heritage site, it is also the largest ancient architectural complex in northeast China, with an area exceeding $60,000 \mathrm{~m}^{2}$. Currently, all buildings and courtyards are well preserved, and various facilities have been restored to their original Qing dynasty (AD 1636-1912) forms. In this study, three traditional palace courtyards were selected, namely Qingning Palace, with a single courtyard (planar dimensions $69 \mathrm{~m} \times 68 \mathrm{~m}$ and $2.5 \mathrm{~m}$-high courtyard walls), East Palace, with three courtyards (planar dimensions $105 \mathrm{~m} \times 25 \mathrm{~m}$ and $2.7 \mathrm{~m}$-high courtyard walls), and West Palace, with multiple courtyards (planar dimensions $115 \mathrm{~m} \times 21 \mathrm{~m}$ and $3.8 \mathrm{~m}$-high courtyard walls). Three courtyards in Shenyang Imperial Palace were selected for measurement and their sound fields were simulated; furthermore, results were cross-verified to ensure the accuracy and universality of the simulation. Figure 3a shows the layout of the West Palace. The measurement process basically followed the international standard ISO 3382-1 [43]. (Note that ISO 3382 is usually used for enclosed performance spaces, such as concert halls. The courtyards in Chinese Buddhist temples in this paper are semi-closed spaces, and some have certain performance functions. However, because of the lack of measurement specifications for these kinds of semi-closed spaces, this study refers to some measurement methods and parameters of ISO 3382). During field measurement, a dodecahedron speaker was used as the sound source and placed at an appropriate location in each courtyard. After the speaker produced pink noise at $100 \mathrm{~dB}$ or higher, onsite RT and SPL measurements were taken for each courtyard. Figure 4 shows average values for the measured EDT of each courtyard 
in Shenyang Imperial Palace. Next, SketchUp software was employed to create a courtyard model of Shenyang Imperial Palace, which was imported into Odeon to simulate the sound field. Figure $3 \mathrm{~b}$ shows the simulated sound field model of West Palace. Acoustic parameters of courtyard material mainly included absorption and scattering coefficients. The absorption coefficient of a particular material was selected from the software's built-in material parameter library; alternatively, values of similar materials were referred to in acoustic reference books $[37,38]$. The scattering coefficient of a particular material was first set by considering both the outer surface condition of the material and the simplification degree of the acoustic model; the coefficient was repeatedly adjusted according to the difference between the sound field's simulated and measured results. Based on this strategy, determinations were made for reference values of the absorption and scattering coefficients of materials that are commonly used in ancient temples (Table 2). For courtyard sound fields that were simulated using the parameters in Table 2, differences between the simulated and measured values are shown in Figure 5. For most SPLs, differences for each frequency ranged from $-10 \mathrm{~dB}$ to $10 \mathrm{~dB}$, with differences in middle frequencies mostly ranging from $-5 \mathrm{~dB}$ to $5 \mathrm{~dB}$. For most reverberation times, the ratio of the difference between the simulated and measured EDT to the measured EDT ranged from $-30 \%$ to $30 \%$, and from $-20 \%$ to $20 \%$ for middle frequencies. In general, errors were lower for middle and high frequencies than for low frequencies.

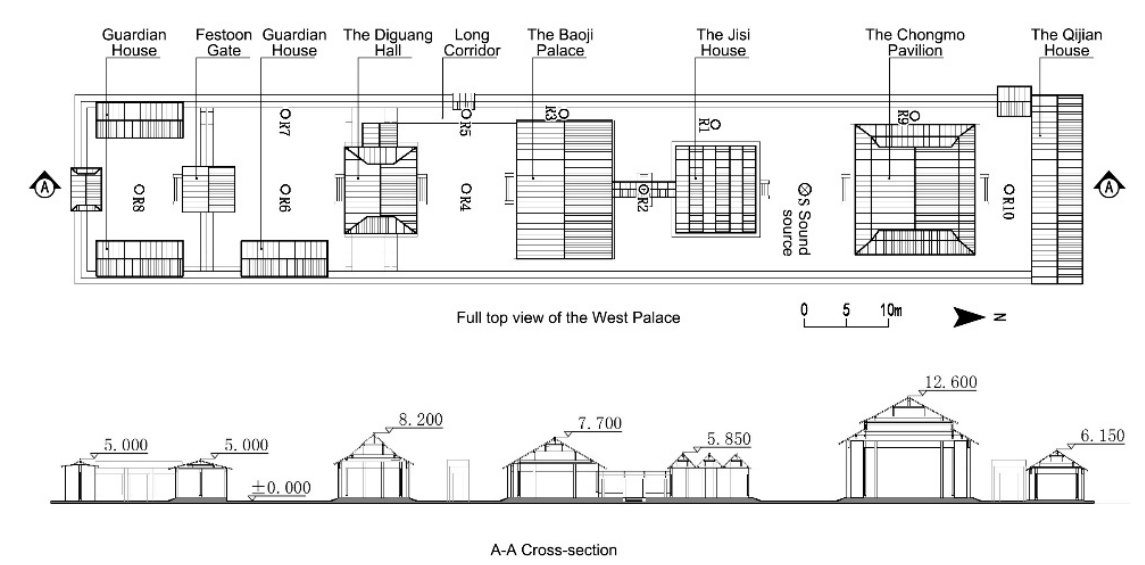

(a)

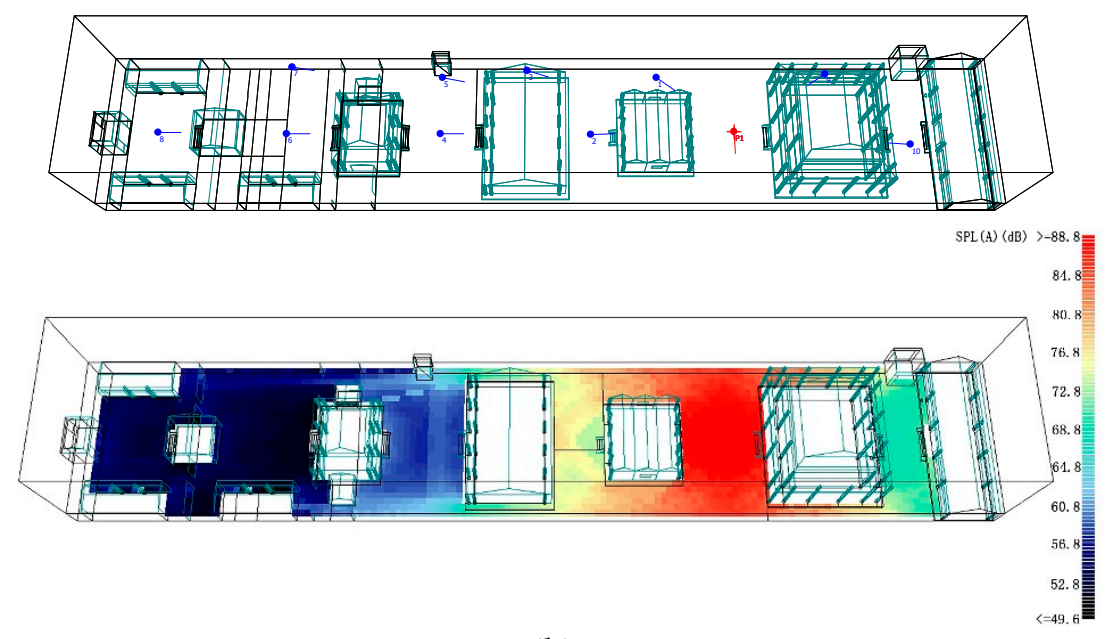

(b)

Figure 3. Survey mapping and sound-field simulation diagram of the West Palace. (a) The top view and cross-sectional view of the West Palace. (b) The acoustic model diagram and sound pressure level (SPL) distribution diagram of the West Palace. 


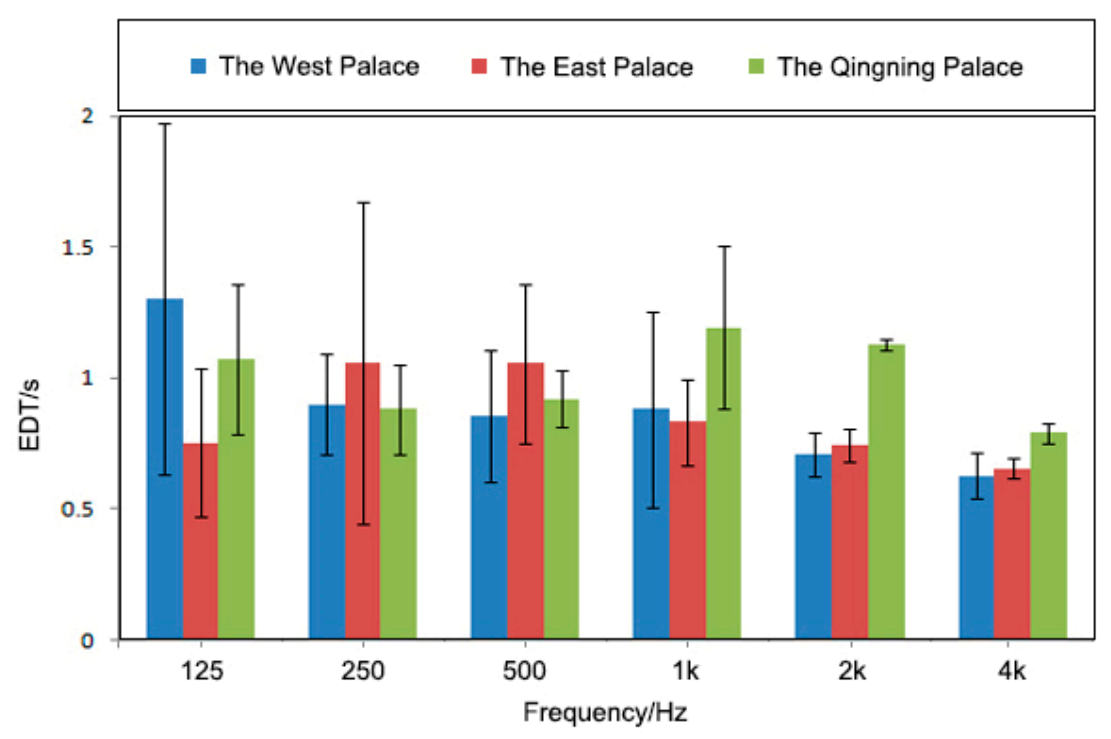

Figure 4. Average values of measured EDT in three traditional courtyards.

Table 2. Sound absorption coefficient and scattering coefficient of outdoor enclosure courtyard materials.

\begin{tabular}{lccccccc}
\hline \multirow{2}{*}{ Material } & \multicolumn{9}{c}{ Sound Absorption Coefficient at the Following Frequency (Hz) } & \multirow{2}{*}{$\begin{array}{c}\text { Scattering } \\
\text { Coefficient }\end{array}$} \\
\cline { 2 - 6 } & $\mathbf{1 2 5}$ & $\mathbf{2 5 0}$ & $\mathbf{5 0 0}$ & $\mathbf{1 0 0 0}$ & $\mathbf{2 0 0 0}$ & $\mathbf{4 0 0 0}$ & 0.50 \\
\hline Glazed tile roof [46] & 0.01 & 0.01 & 0.01 & 0.01 & 0.02 & 0.02 & 0.1 \\
Glass window [47] & 0.35 & 0.25 & 0.18 & 0.12 & 0.07 & 0.04 & 0.05 \\
Rendered wall [47] & 0.03 & 0.03 & 0.03 & 0.04 & 0.05 & 0.07 & 0.10 \\
Red brick wall * & 0.11 & 0.08 & 0.07 & 0.06 & 0.05 & 0.05 & 0.15 \\
Stone step * & 0.01 & 0.01 & 0.02 & 0.02 & 0.02 & 0.05 & 0.05 \\
Hard paving * & 0.01 & 0.01 & 0.02 & 0.02 & 0.02 & 0.05 & 0.20 \\
Wooden door [48] & 0.16 & 0.15 & 0.10 & 0.10 & 0.10 & 0.10 & 0.40 \\
Bucket arch [47] & 0.19 & 0.43 & 0.44 & 0.40 & 0.42 & 0.40 & 0.30 \\
Wooden eave column [45] & 0.1 & 0.07 & 0.05 & 0.05 & 0.05 & 0.05 & 0.70 \\
Mud floor [46] & 0.15 & 0.25 & 0.40 & 0.55 & 0.60 & 0.60 & 0.60 \\
Lawn [46] & 0.11 & 0.26 & 0.6 & 0.69 & 0.92 & 0.99 & \\
\hline
\end{tabular}

Note: The sound absorption coefficient of the material marked with * was obtained by referring to similar material suggested by Odeon software.

The simulation accuracy of this study did not entirely meet the common acoustic criteria in interior space, which requires that the simulated error of RT should be less than its JND [41]. However, we considered the errors in this study to be within an acceptable range based on the following reasons: (1) There was a lack of related research about standard acoustic parameters of materials in ancient Chinese architecture. The sound absorption coefficients of ancient materials used in our simulation research were from those of relevant building materials in acoustic reference books, which may be different from the actual sound absorption coefficients of the site's materials; (2) The measurements were conducted in outdoor spaces, the courtyard scale was large, reverberation resulted from multiple reflections, and the acoustic model simplified the building and the courtyard in the simulation process. These factors would affect the measurements and simulation accuracy in this study; (3) Relative values from courtyard sound field simulation results were compared and analysed, and the results of the middle frequency (the bands of $500 \mathrm{~Hz}$ and $1000 \mathrm{~Hz}$, which also is the main frequency range of human language), wherein errors were relatively small, were chosen as representative data; (4) The purpose of this study was not to obtain acoustic results for engineering calculations but to analyse characteristics of the courtyard sound field in Chinese Buddhist temples by means of comparing changing trends of the sound field. 


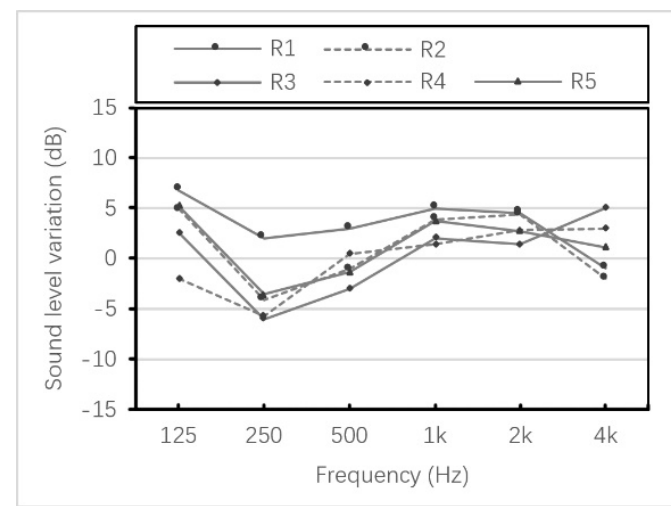

(a)

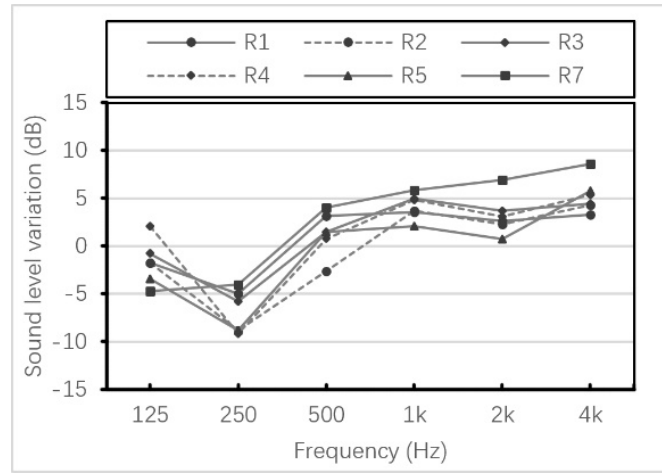

(c)

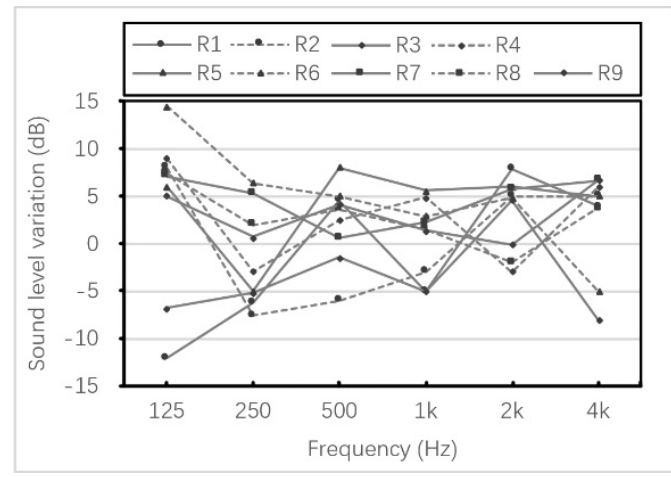

(e)

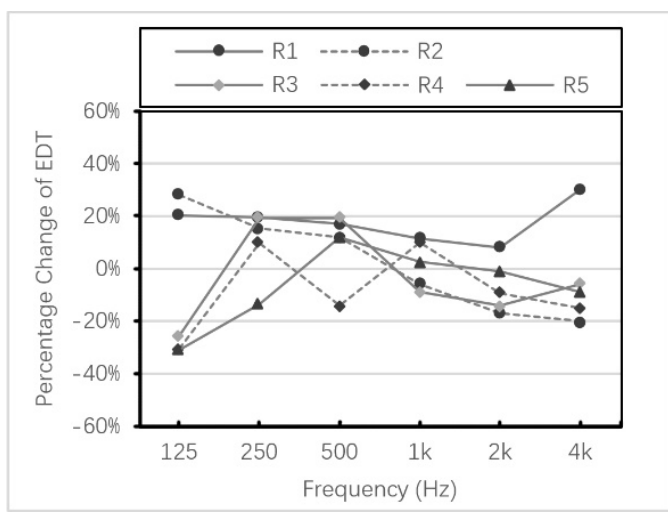

(b)

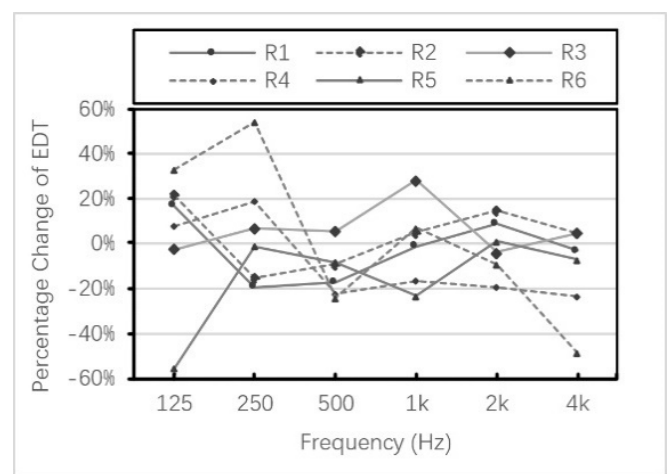

(d)

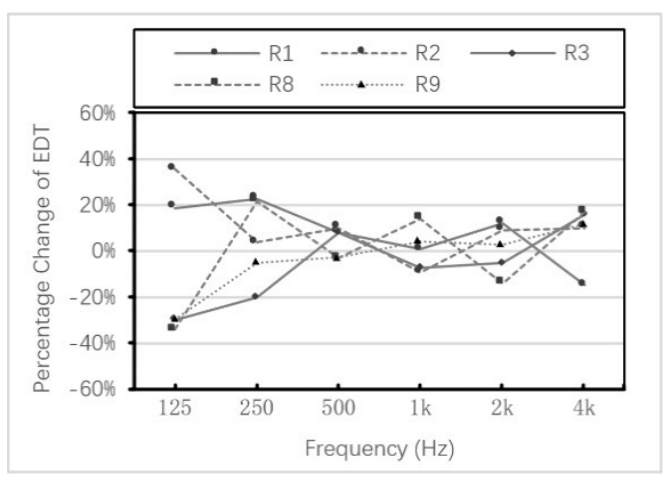

(f)

Figure 5. Broken-line graph of sound level differences and EDT percentage differences between measured and simulated results for Shenyang Imperial Palace courtyards. (a) Differences in Qingning Hall sound levels. (b) Percentage differences in Qingning Hall EDT. (c) Differences in East Hall sound levels. (d) Percentage differences in East Hall EDT. (e) Differences in West Hall sound levels. (f) Percentage differences in West Hall EDT.

\section{Results and Discussion}

After establishing a sound field model for the standard temple form and determining the absorption and scattering coefficients of building materials, the sound field model's spatial elements were modified. Sound field parameter changes were then analysed in order to explore how spatial elements impact Han Buddhist temples' courtyard sound fields. These elements included courtyard walls, partition walls, bell towers, and courtyard interface materials. 


\subsection{Height of Courtyard Walls}

Most urban Chinese Buddhist temples have courtyard walls. Field surveys revealed that temple courtyard walls are generally 2 to $3 \mathrm{~m}$ high—sufficient to block outside sights and noises, creating a quiet atmosphere for Buddhist religious practice. In this study, the simulation model was set to include wall heights of $0 \mathrm{~m}$ (no wall), $1.5 \mathrm{~m}, 3 \mathrm{~m}, 4.5 \mathrm{~m}, 6 \mathrm{~m}$, and $7.5 \mathrm{~m}$. For each courtyard, Figure $6 \mathrm{a}, \mathrm{b}$ show the SPL(A) and its standard deviation, respectively. The first courtyard's SPL(A) was relatively stable with every $1.5 \mathrm{~m}$ increase in wall height, leading to an increase of less than $0.7 \mathrm{dBA}$ in SPL(A). For the second through fourth courtyards, SPL(A) increased along with wall height; this was attributed to amplified sound reflection. For every $1.5 \mathrm{~m}$ increase in wall height, SPL(A) rose, on average, from about 0.7 to $1.7 \mathrm{dBA}, 1$ to $2 \mathrm{dBA}$, and 1.5 to $2.3 \mathrm{dBA}$ in the second, third, and fourth courtyards, respectively. The standard deviation (STD) of the SPL(A) at sound receivers in each courtyard decreased significantly with increasing wall height. In the second, third, and fourth courtyards, the standard deviation of the SPL(A) with a wall height of $7.5 \mathrm{~m}$ was smaller by about $2.4 \mathrm{dBA}, 2.1 \mathrm{dBA}$, and $3.1 \mathrm{dBA}$, respectively, compared to those without a wall. This indicates that increased courtyard wall height led to higher sound field uniformity, which may be attributed to higher courtyard walls increasing sound reflection.

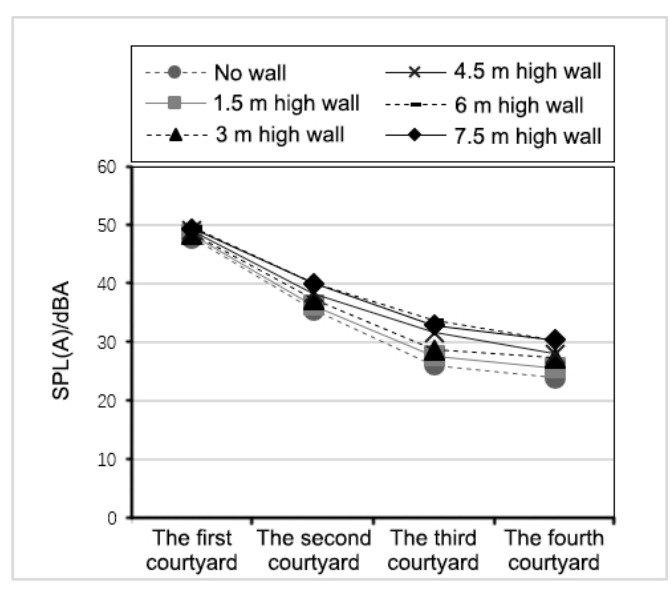

(a)

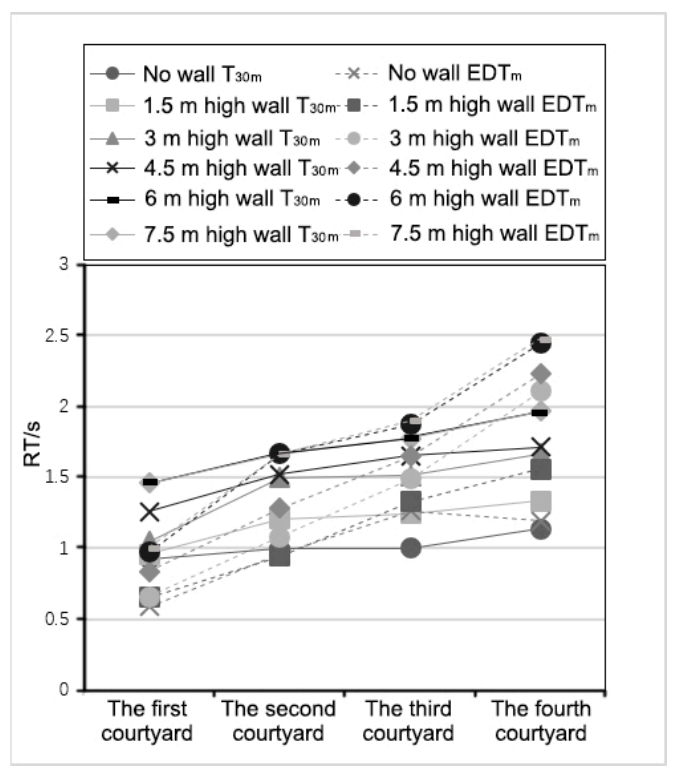

(c)

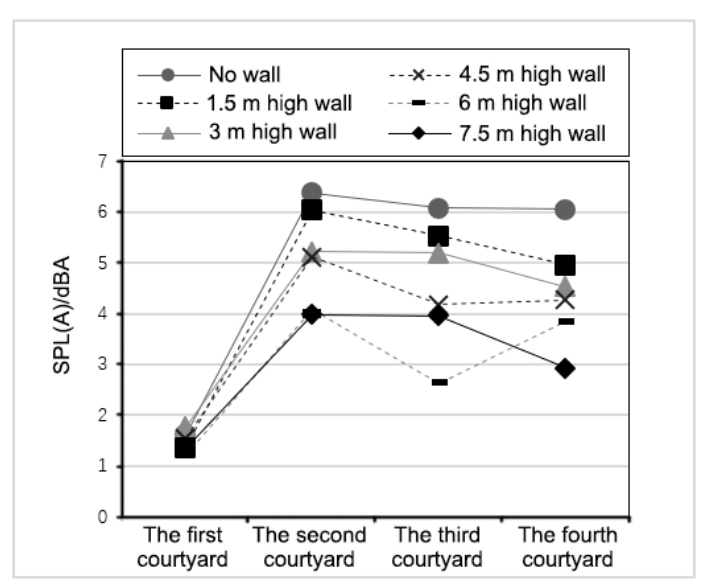

(b)

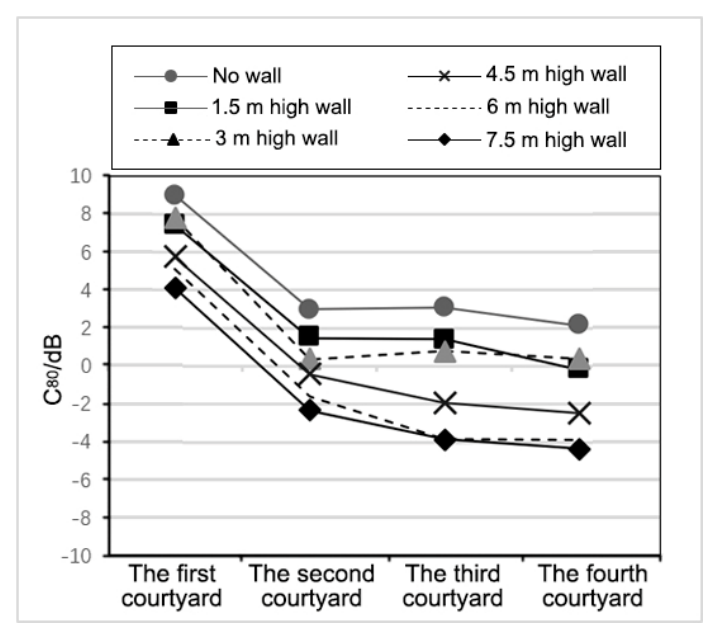

(d)

Figure 6. Diagrams of the effects of wall height on courtyard sound fields. (a) Variation in weighted SPL(A). (b) Variation in the standard deviation of SPL(A). (c) Variation in RT. (d) Variation in $\mathrm{C}_{80}$. 
As shown in Figure 6c, courtyard RT rose with increasing wall height. The $\mathrm{T}_{30 \mathrm{~m}}$ of the first through fourth courtyards with a wall height of $7.5 \mathrm{~m}$ was higher by about $0.54 \mathrm{~s}(58 \%), 0.67 \mathrm{~s}(67 \%), 0.77 \mathrm{~s}$ $(77 \%)$, and $0.83 \mathrm{~s}(73 \%)$, respectively, compared to those without a wall. EDT $\mathrm{m}$ increased by about $0.42 \mathrm{~s}(71 \%), 0.71 \mathrm{~s}(74 \%), 0.64 \mathrm{~s}(51 \%)$, and $1.29 \mathrm{~s}(108 \%)$, respectively. In addition, the results showed that after the wall height was greater than the height of the sound source, courtyard SPL(A) and RT no longer changed with increasing wall height. In the meantime, Figure $6 \mathrm{~d}$ indicates that $C_{80}$ decreased with increased wall height. For the first through fourth courtyards, in the presence of a $7.5 \mathrm{~m}$ high wall, courtyard $\mathrm{C}_{80}$ was lower by $4.89 \mathrm{~dB}, 5.35 \mathrm{~dB}, 6.93 \mathrm{~dB}$, and $6.45 \mathrm{~dB}$, respectively, than their counterparts in the absence of a wall. All decreasing values exceeded the JND. These results indicate that changes to temple courtyard wall height will affect courtyard sound fields.

\subsection{Courtyard Partition Walls}

Compared to other types of traditional courtyards, courtyards of Han Chinese Buddhist temples have an important feature; that is, there is no separate partition wall between courtyards. This not only allows visitors to choose a tour path, but also increases the viewing angle of the main Buddhist halls, which enriches the temple's landscape structure [1]. This study simulated courtyard sound fields with and without courtyard partition walls, and courtyard walls were set to a $3 \mathrm{~m}$ height. Figure $7 \mathrm{a}$ illustrates each courtyard's SPL(A) changes. It shows that SPL(A) did not differ significantly with and without partition walls in the first and second courtyards. It also shows that SPL(A) was significantly smaller with a partition wall than without one in the third and fourth courtyards, decreasing by 4.7 and $6.0 \mathrm{dBA}$, respectively. This significant decrease in SPL(A) was analysed using a sound-ray diagram (Figure 8), which revealed that the decrease was mainly due to courtyard partition walls blocking direct sound. In addition, the results showed that additional courtyard partition walls would not lead to significant changes in $\mathrm{T}_{30 \mathrm{~m}}$. After courtyard partition walls were introduced into the model, there were no significant changes in $\mathrm{EDT}_{\mathrm{m}}$ in the first courtyard; however, $\mathrm{EDT}_{\mathrm{m}}$ of the second through fourth courtyards increased by $0.51 \mathrm{~s}(52 \%), 0.58 \mathrm{~s}(42 \%)$, and $0.35 \mathrm{~s}(21 \%)$, respectively (Figure $7 \mathrm{~b}$ ). As seen in Figure $7 \mathrm{c}$, after the introduction of partition walls, the $\mathrm{C}_{80}$ of the second through fourth courtyards decreased by $4.8 \mathrm{~dB}, 2.9 \mathrm{~dB}$, and $6.7 \mathrm{~dB}$. Figure $7 \mathrm{~d}$ shows that there was no significant change in (1-IACC $\mathrm{E}_{\mathrm{E} 3}$ ) in the first through third courtyards, regardless of partition walls; however, the fourth courtyard exhibited a decrease in the value of $\left(1-\mathrm{IACC}_{\mathrm{E} 3}\right)$ by 0.09 after the introduction of the partition wall. These results show that the absence of courtyard partition walls would not lead to significant SPL(A) changes in the first and second courtyards, but it would increase the SPL(A) and $\left(1-\mathrm{IACC}_{\mathrm{E} 3}\right)$ values in the third and fourth courtyards. Moreover, the absence of courtyard partition walls would decrease the $\mathrm{EDT}_{\mathrm{m}}$ of the second, third, and fourth courtyards while increasing their $\mathrm{C}_{80}$, making music clearer. In short, the absence of courtyard partition walls will have an impact on courtyard sound fields. 


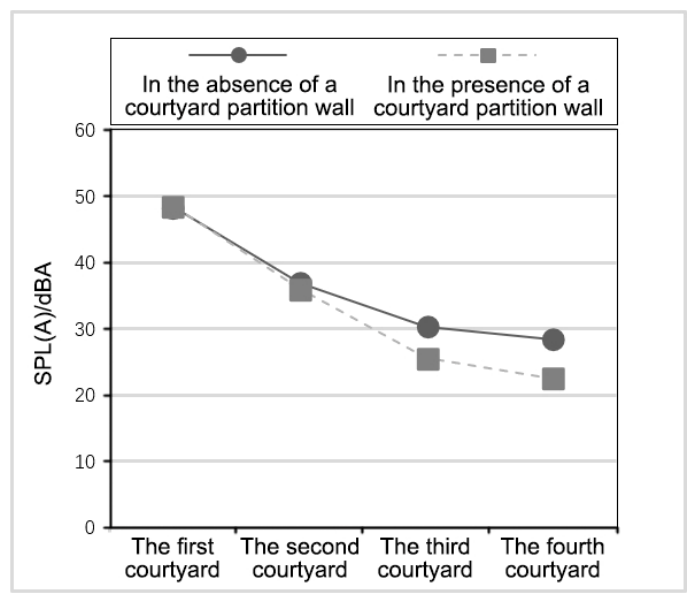

(a)

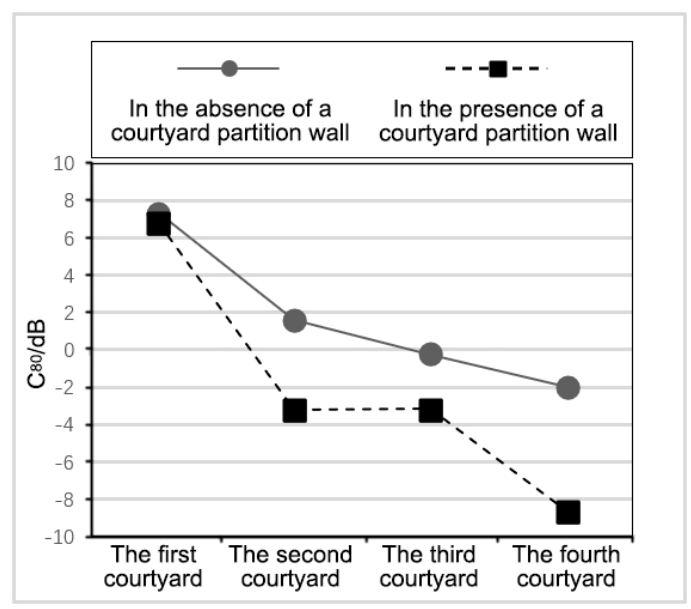

(c)

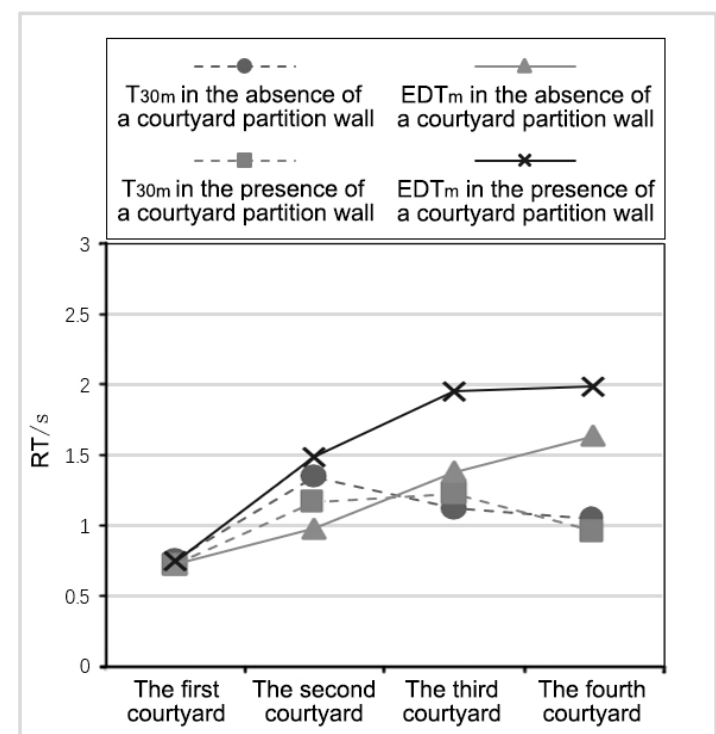

(b)

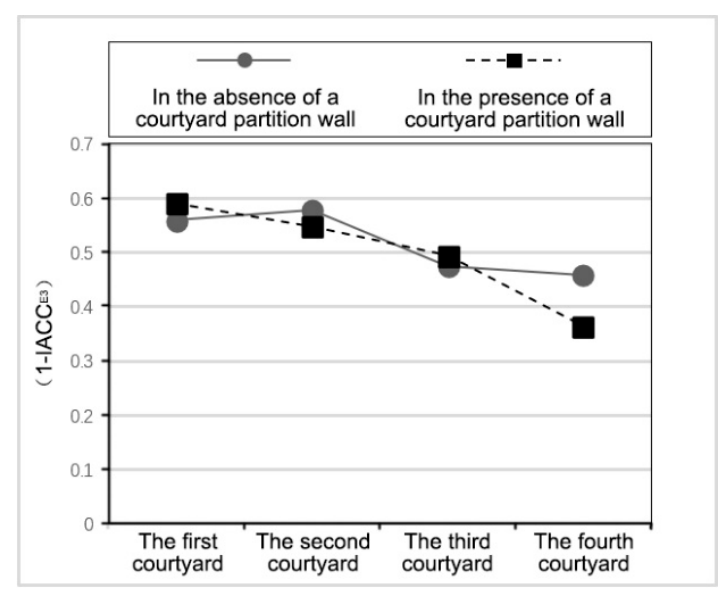

(d)

Figure 7. Diagrams of the effects of courtyard partition walls on courtyard sound fields. (a) Variation in SPL(A). (b) Variation in RT. (c) Variation in $\mathrm{C}_{80}$. (d) Variation in (1-IACC $\left.\mathrm{E}_{3}\right)$.

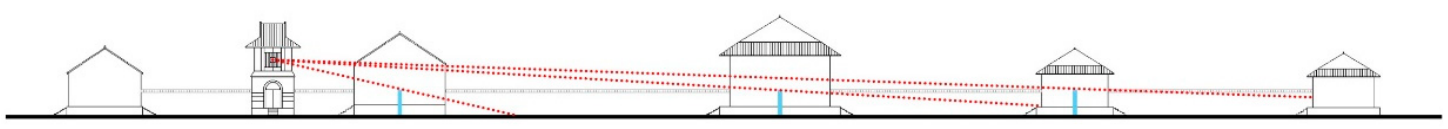

Figure 8. Diagram of sound rays.

\subsection{The Position and Height of the Bell Tower}

The history of bell towers in Buddhist temples dates back to the Tang dynasty (AD 618-907). Figure 1 illustrates a general change in the trend of bell tower positioning. Under the Song dynasty (AD 960-1279), the bell tower was placed in a corner of the first courtyard; under the Qing dynasty, it was placed at a fixed position opposite the drum tower. The bell and drum towers sit on either side of the central axis in the first courtyard [3]. In this study, Buddhist temple sound fields with different bell tower positions that corresponded to either the Qing or the Song dynasty were simulated, with a $3 \mathrm{~m}$ courtyard wall height, and the results were compared to cases where the bell tower was placed in the centre of the first courtyard (results presented in Figure 9a,b). There was no significant difference between the three bell-tower position conditions in the SPL(A) of the first courtyard. There was also no significant difference between the two bell-tower position conditions of the Qing and Song dynasties 
regarding the SPL(A) of the second through fourth courtyards; nevertheless, the SPL(A) values for both were higher-by about $2.0 \mathrm{dBA}, 5.1 \mathrm{dBA}$, and $4.8 \mathrm{dBA}$ and $4.1 \mathrm{dBA}, 6.0 \mathrm{dBA}$, and $6.3 \mathrm{dBA}$, respectively - than those of their counterparts when the central bell tower was positioned in the first courtyard. Meanwhile, the standard deviation of SPL(A) in the second and third courtyards was higher by about 1 to $2 \mathrm{dBA}$ for the Qing dynasty temple layout than for the other two layouts, whereas there was no significant difference between the three conditions in the SPL(A) of the fourth courtyard. The results indicate that different positions of the bell tower had no significant or regular effects on RT or the standard deviation of RT.

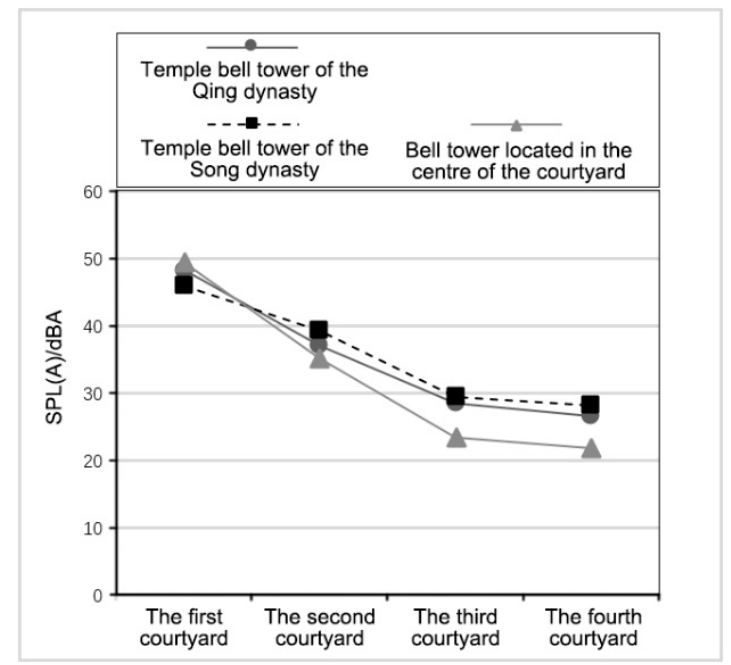

(a)

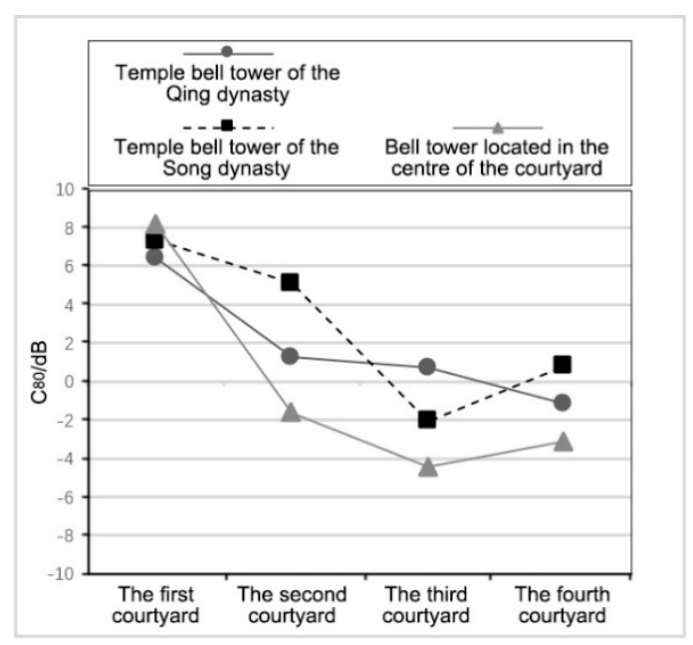

(c)

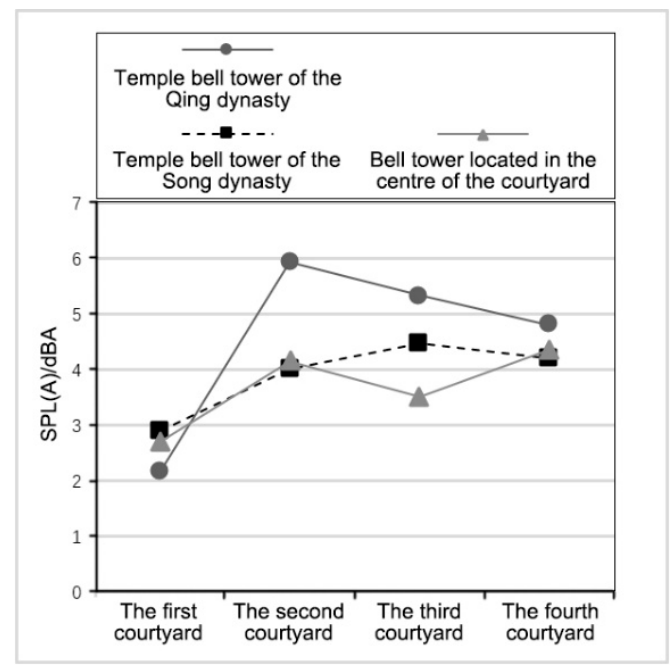

(b)

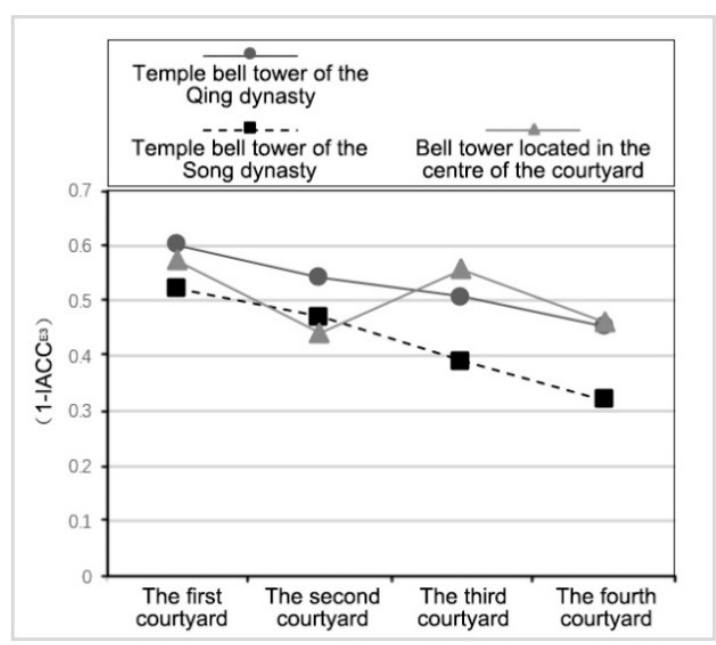

(d)

Figure 9. Diagrams of the effects of bell tower position on courtyard sound fields. (a) Variation in SPL(A). (b) Variation in the standard deviation of SPL(A). (c) Variation in $\mathrm{C}_{80}$. (d) Variation in $\left(1-\mathrm{IACC}_{\mathrm{E} 3}\right)$.

Figure $9 \mathrm{c}$ shows that a modification in bell tower position did not cause significant changes in $\mathrm{C}_{80}$ in the first courtyard, but $C_{80}$ in the second through fourth courtyards, which featured Qing and Song dynasty bell tower layouts, was higher than their counterparts with a central bell tower layout. For the second through fourth courtyards, which featured the Qing dynasty layout, there were increases in $\mathrm{C}_{80}$ values of $2.9 \mathrm{~dB}, 5.1 \mathrm{~dB}$, and $2.0 \mathrm{~dB}$, respectively. For the second through fourth courtyards that featured the Song dynasty layout, $\mathrm{C}_{80}$ values increased by $6.8,2.4$, and $3.9 \mathrm{~dB}$, respectively. As 
shown in Figure 9d, the (1-IACC $\mathrm{E}_{\mathrm{E} 3}$ ) values of the first through fourth courtyards, which featured the Qing dynasty layout, were higher by $0.079,0.071,0.12$, and 0.13 , respectively, when compared to their counterparts with the Song dynasty layout. Differences were above the JND (i.e., 0.075) except for the second courtyard. These results show that in addition to affecting courtyard landscape, the bell tower's position also affects the SPL(A), $\mathrm{C}_{80}$, and (1-IACC $\mathrm{E}_{\mathrm{E}}$ ) values of each courtyard, except for the first courtyard. Bell tower layout had small effects on the RT and RT standard deviation in the courtyards.

In large Han Chinese Buddhist temples, the bell is placed on a two-storey bell tower that hangs about $6 \mathrm{~m}$ above the ground. Simulation results indicate that with a $3 \mathrm{~m}$ courtyard wall height, an increasing bell tower height (i.e., raising the position of the sound source) would lead to a smaller average SPL(A). As the sound source was raised from $1.5 \mathrm{~m}$ to $7.5 \mathrm{~m}$ above the ground, SPL(A) decreased by $1.9 \mathrm{dBA}, 1.2 \mathrm{dBA}, 2.4 \mathrm{dBA}$, and $2.3 \mathrm{dBA}$ in the first through fourth courtyards, respectively, while the standard deviation of SPL(A) increased by $1.1 \mathrm{dBA}, 2.1 \mathrm{dBA}, 1.8 \mathrm{dBA}$, and $1.7 \mathrm{dBA}$, respectively. This may be attributed to the sound source's higher position, which reduced sound reflection from the courtyard walls. These results show that the SPL(A) of each courtyard would decrease in the presence of a two-storey bell tower compared with a layout in which the bell is placed directly on the ground without a tower. Of course, an increase in sound source height, especially when it exceeds courtyard wall height, would increase the bell sound's propagation distance outside the temple and increase the temple's influence on the surrounding area. The sound source height also affected the courtyards' RT (Figure 10a). The $\mathrm{T}_{30 \mathrm{~m}}$ and $\mathrm{EDT}_{\mathrm{m}}$ of each courtyard reached maximum values when the sound source was $3 \mathrm{~m}$ above the ground (i.e., the same height as the wall), while a greater or lesser sound source height would significantly decrease $T_{30 \mathrm{~m}}$. Compared to the maximum $T_{30 \mathrm{~m}}$ value for a sound source at a height of $3 \mathrm{~m}$, the $\mathrm{T}_{30 \mathrm{~m}}$ value for a sound source at other heights in the first through fourth courtyards dropped by about $42 \%$ to $76 \%, 16 \%$ to $29 \%, 9 \%$ to $39 \%$, and $16 \%$ to $42 \%$, respectively. $\mathrm{EDT}_{\mathrm{m}}$ did not change significantly in the first courtyard, but it decreased by $20 \%$ to $47 \%, 51 \%$ to $119 \%$, and $33 \%$ to $98 \%$ in the second through fourth courtyards, respectively. The reduced $\mathrm{T}_{30 \mathrm{~m}}$ and $\mathrm{EDT}_{\mathrm{m}}$ values exceeded the JND. As shown in Figure 10b, when the sound source was $6 \mathrm{~m}$ high, $\mathrm{C}_{80}$ reached maximum values in the second, third, and fourth courtyards, with a greater or lesser sound source height leading to decreases. $\mathrm{C}_{80}$ decreased by $4.3 \mathrm{~dB}$ at most. These results indicate that the height and position of a temple's bell tower (sound source) will affect a Buddhist temple's courtyard sound field.

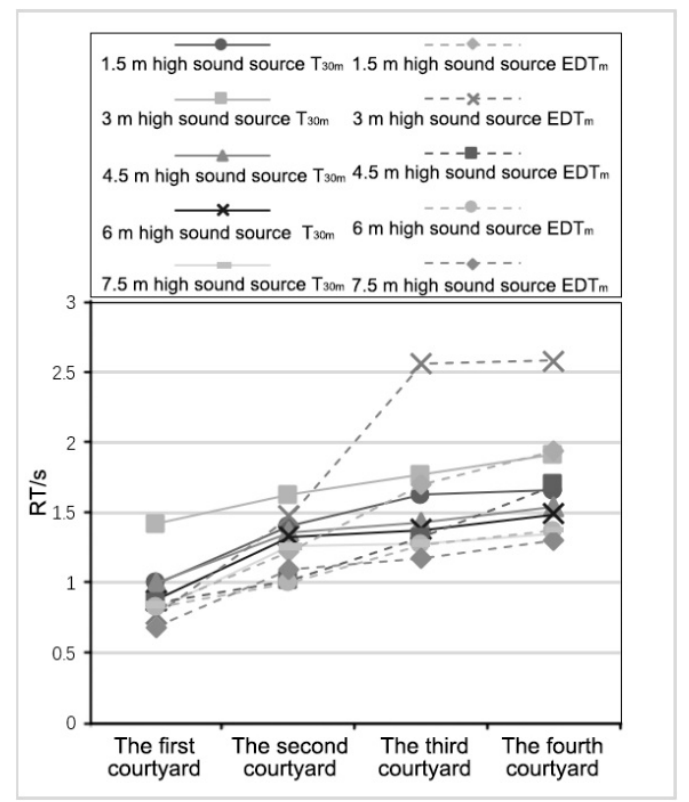

(a)

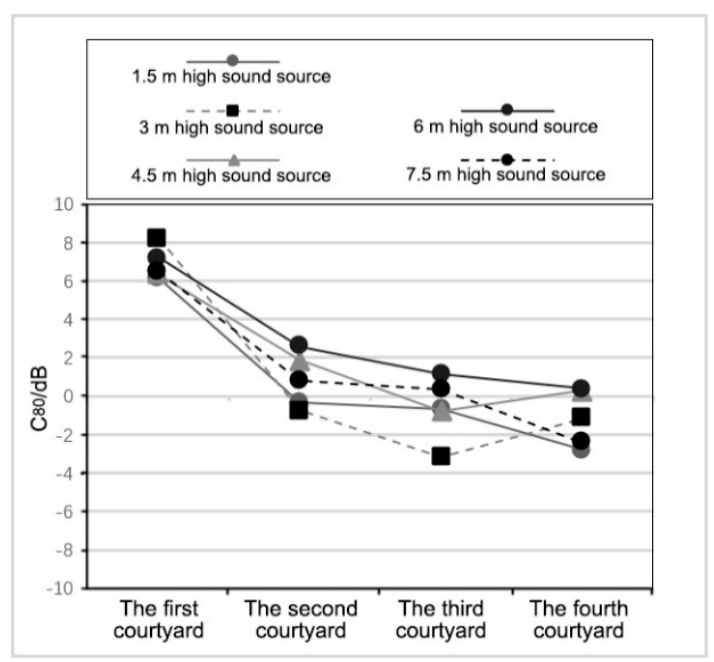

(b)

Figure 10. Diagrams of the effects of bell tower height on courtyard sound fields. (a) Variation in RT. (b) Variation in $\mathrm{C}_{80}$. 


\subsection{Courtyard Interface Materials}

The building materials used in Han Chinese Buddhist temples include bricks, wood, tiles, and stones. Temple courtyard walls are mostly made from smooth bricks with small sound absorption coefficients. In the sound field simulation model, the sound absorption coefficients of temple courtyard walls at various frequency bands were set in the range of 0.01 to 0.03 . The scattering coefficient was set to 0.15 . Studies show that when the courtyard wall is made from different materials or with different climbing plants, its sound absorption and scattering coefficients will change [49]; a vegetation-covered wall will have a sound absorption coefficient of 0.6 to 0.7 at frequencies of $125 \mathrm{~Hz}$ to $4 \mathrm{kHz}$ [50]. In the interest of research simplification, this study assumed that at each frequency band the sound absorption coefficient of the temple courtyard wall was 0 for smooth brick walls, 0.3 for brick walls that were covered to some extent with climbing plants, and 0.6 for walls covered with greenery growing in soil. Moreover, if hedges of sparse foliage enclosed the temple, the sound absorption coefficient would be assumed as 0.9 , since sound can easily pass through hedges, and each scattering coefficient was set to 0.1. Courtyard sound fields were simulated for the aforementioned four types of temple courtyard walls. As shown in Figure 11a, for every increase of 0.3 in sound absorption coefficient, the SPL(A) of the second and third courtyards decreased by 1.2 to $4.0 \mathrm{dBA}$, and that of the fourth courtyard decreased by 2.2 to $4.6 \mathrm{dBA}$. In particular, when the sound absorption coefficient increased from 0.6 to 0.9 , the SPL(A) dropped significantly. Figure $11 \mathrm{~b}$ shows that increases in courtyard wall sound absorption coefficients increased the standard deviation of SPL(A), resulting in the non-uniform distribution of SPL(A) in courtyards. As shown in Figure 11c, for every increase of 0.3 in the sound absorption coefficient, $\mathrm{T}_{30 \mathrm{~m}}$ decreased by $9 \%$ to $32 \%, 5 \%$ to $14 \%, 5 \%$ to $6 \%$, and $9 \%$ to $18 \%$ in the first, second, and fourth courtyards, respectively. For every increase of 0.3 in the sound absorption coefficient, $\mathrm{EDT}_{\mathrm{m}}$ decreased by $5 \%$ to $12 \%, 2 \%$ to $7 \%, 7 \%$ to $21 \%$, and $11 \%$ to $28 \%$ in the first through fourth courtyards, respectively, with most of the decreases exceeding the JND. Figure $11 \mathrm{~d}$ shows that if the sound absorption coefficients of temple courtyard walls increased from 0 to $0.9, \mathrm{C}_{80}$ increased by $2.1 \mathrm{~dB}, 1.9 \mathrm{~dB}, 4.4 \mathrm{~dB}$, and $3.6 \mathrm{~dB}$ in the first through fourth courtyards, respectively. This shows that when compared with various vegetation-covered walls or hedges, smooth brick walls lead to higher SPL(A) with more uniform distribution in sound fields of Buddhist temples, while increasing RT and decreasing $\mathrm{C}_{80}$.

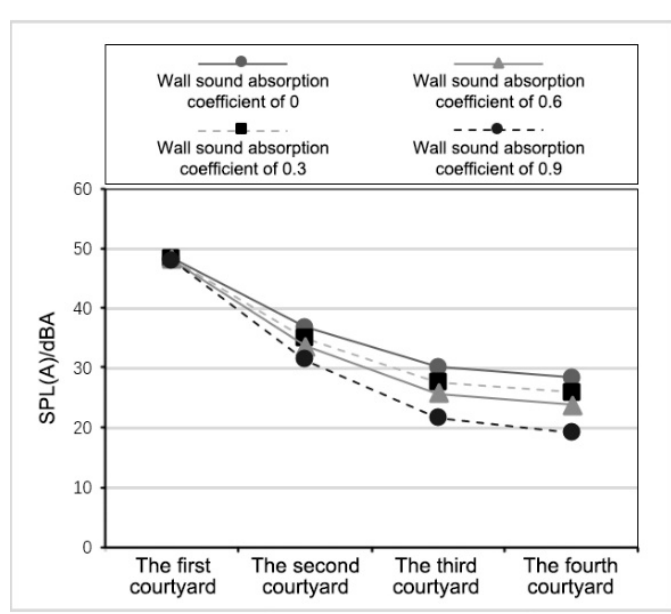

(a)

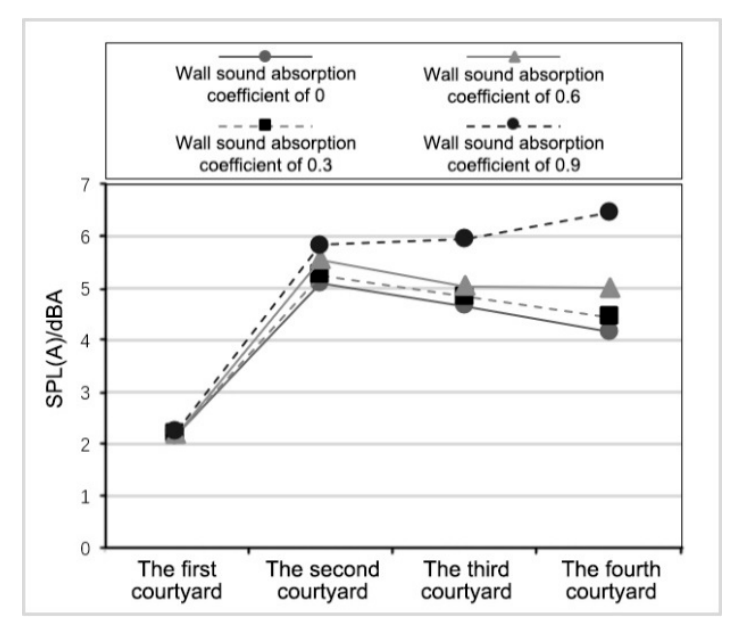

(b)

Figure 11. Cont. 


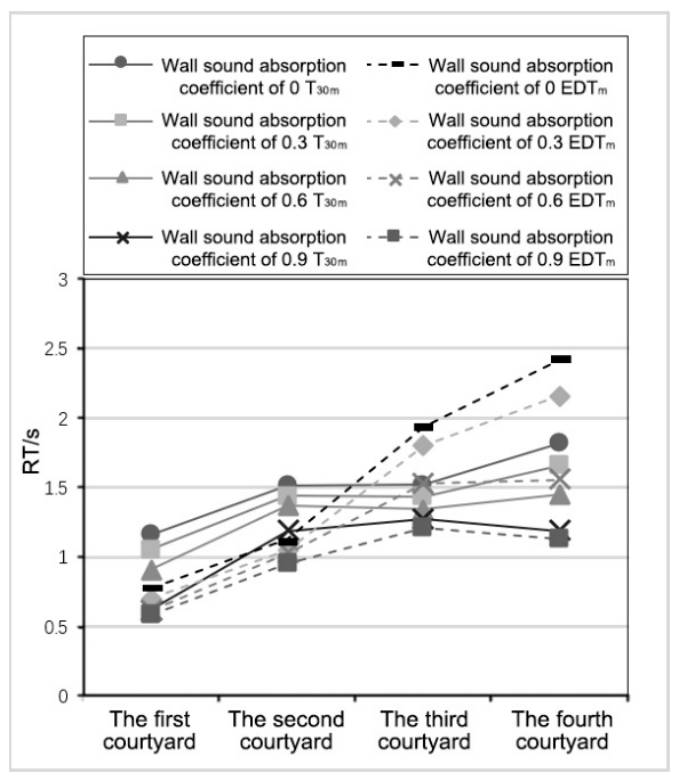

(c)

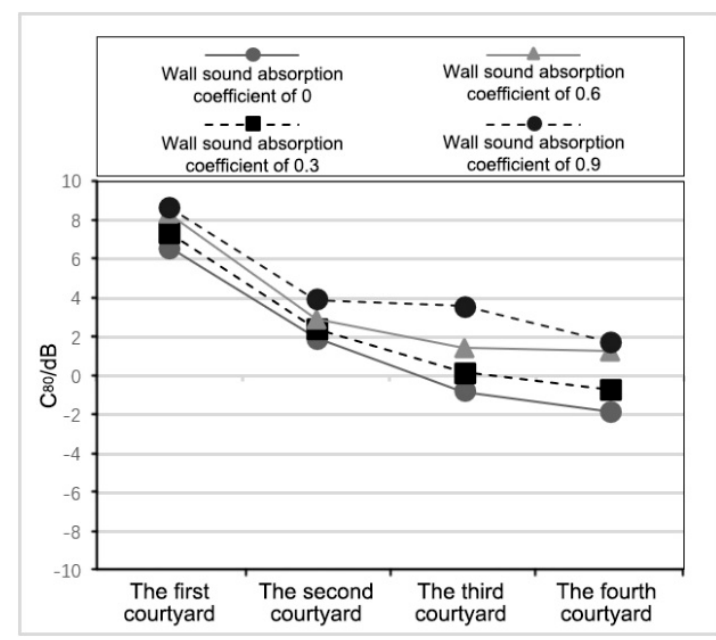

(d)

Figure 11. Diagrams of the effects of wall materials on courtyard sound fields. (a) Variation in SPL(A).

(b) Variation in the standard deviation of SPL(A). (c) Variation in RT. (d) Variation in $\mathrm{C}_{80}$.

Courtyard grounds of traditional Buddhist temples are generally paved with hard bricks or stones, with partial areas of natural vegetation (greenery) or bare soil. In this study, each courtyard's sound field was simulated with three different courtyard ground compositions: $100 \%$ greenery, $100 \%$ bare soil, or $100 \%$ stone pavement. Figure 12a shows that there was almost no difference in SPL(A) between courtyard sound fields with ground compositions that were either greenery or bare soil. The sound level was higher in the stone pavement courtyard than in courtyards that had the other two types of ground, by about $1.6 \mathrm{dBA}$ in the first courtyard; furthermore, the SPL(A) was higher by about 1.3 to $3.8 \mathrm{dBA}$ in the second through fourth courtyards compared with the other two types of ground. Figure $12 \mathrm{~b}$ shows that greenery and bare soil exhibited very similar results with regard to the first courtyard's $\mathrm{EDT}_{\mathrm{m}}$ value; however, for stone pavements, the first courtyard's $\mathrm{EDT}_{\mathrm{m}}$ was about $13 \%$ higher than in the other two scenarios. For the second and third courtyards' $\mathrm{EDT}_{\mathrm{m}}$, greenery had the highest values among the three ground types, with an $\mathrm{EDT}_{\mathrm{m}}$ value for the second courtyard higher by $13 \%$ and $20 \%$ than its counterparts that had bare soil and stone pavement, respectively. For the third courtyard's $\mathrm{EDT}_{\mathrm{m}}$, greenery had values that were $9 \%$ and $29 \%$ higher than bare soil and stone pavement, respectively. In contrast, greenery had the lowest $\mathrm{EDT}_{\mathrm{m}}$ value in the fourth courtyard, which was lower by $9 \%$ and $15 \%$ compared with its bare soil and stone pavement counterparts, respectively. All of these differences exceeded the JND. Figure 12c shows that there was no significant difference between greenery and bare soil in the $\mathrm{C}_{80}$ of each courtyard. For stone pavement, courtyard $\mathrm{C}_{80}$ was higher in the third courtyard by about $1.7 \mathrm{~dB}$ than in the other two types of ground, but the same value was lower by $2.0 \mathrm{~dB}$ in the fourth courtyard. These results indicate that changes in temples' ground material did not have a significant, regular impact on courtyard sound fields. Moreover, the simulation revealed that acoustic parameters of roofing materials had no significant effect on Buddhist temples' courtyard sound fields. It is assumed that this can be attributed to the fact that traditional Buddhist temples in China use sloped roofs, which, in most cases, leads to upward and outward sound reflection. In addition, acoustic parameters of the materials used for temples' exterior windows in the simulation model did not have a significant impact on sound fields of each courtyard; this was likely due to the exterior windows' relatively small area. 


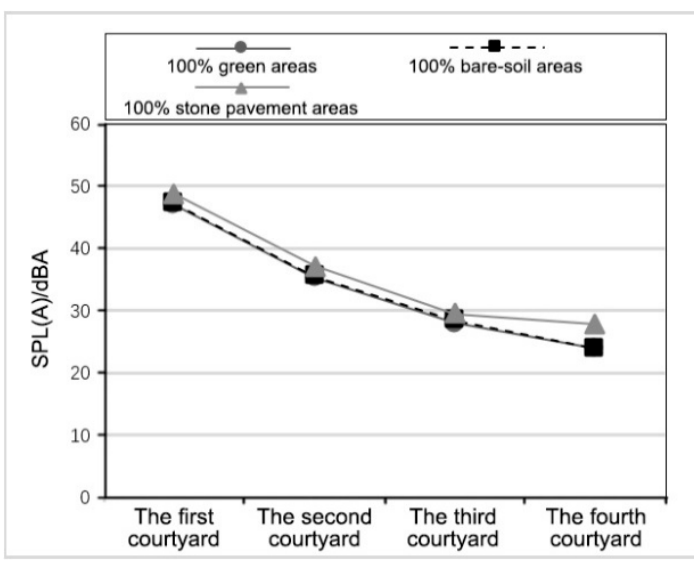

(a)

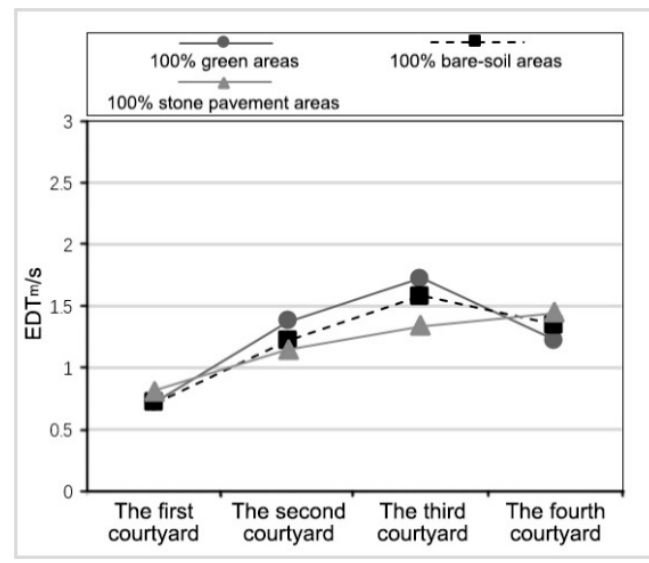

(b)

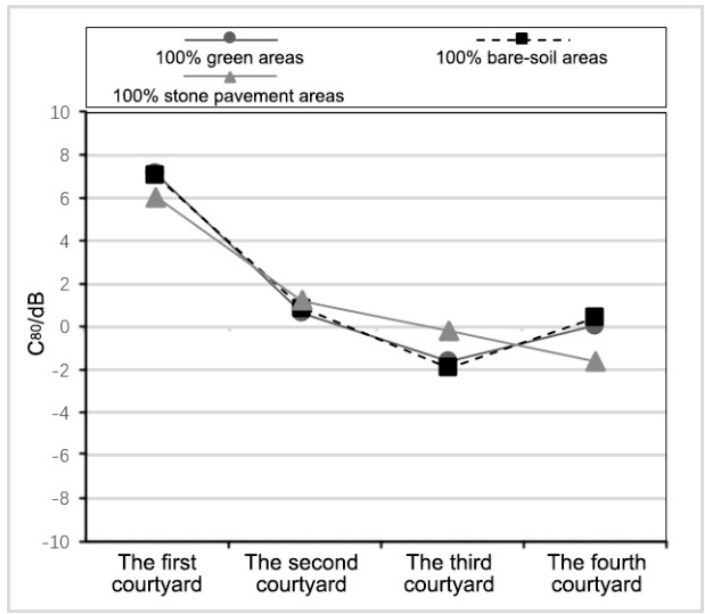

(c)

Figure 12. Diagrams of the effects of flooring materials on courtyard sound fields. (a) Variation in $\mathrm{SPL}(\mathrm{A})$. (b) Variation in $\mathrm{EDT}_{\mathrm{m}}$. (c) Variation in $\mathrm{C}_{80}$.

\section{Conclusions}

This study established and analysed a standard Han Chinese Buddhist temple courtyard sound field model, which yielded the following results.

(1) An increase in temple courtyard wall height will increase sound reflection in courtyards, which will, in turn, significantly increase the SPL(A) of each courtyard and make the sound fields more uniform. As shown by the temple model that was established in this study, for every wall height increase of $1.5 \mathrm{~m}$, the SPL(A) of the second through fourth courtyards increased by 0.7 to $2.3 \mathrm{dBA}$. An increased wall height will increase $\mathrm{RT}$ and decrease $\mathrm{C}_{80}$, to some extent. When wall height exceeds the height of the sound source, the courtyard's sound field will no longer be varied.

(2) Traditional temples usually do not have partition walls between courtyards. The simulation model showed that adding partition walls between courtyards did not have significant effects on the SPL(A) of the first and second courtyards, but it decreased the SPL(A) and (1-IACC $\left.\mathrm{E}_{\mathrm{E} 3}\right)$ of the third and fourth courtyards, which were relatively far from the sound source. Adding courtyard partition walls also increased the $\mathrm{EDT}_{\mathrm{m}}$ of the second through fourth courtyards by $52 \%, 42 \%$, and $21 \%$, respectively, but decreased their $\mathrm{C}_{80}$.

(3) The position of the bell tower affected nearby courtyards' SPL(A). The model showed that there were no significant differences between the Qing and Song dynasties' bell tower layouts regarding the SPL(A) and $\mathrm{C}_{80}$ of the second through fourth courtyards. However, these two layouts led to 
higher SPL(A) and $\mathrm{C}_{80}$ than a third layout in which the bell tower was located at the centre of the first courtyard. The (1- $\mathrm{IACC}_{\mathrm{E} 3}$ ) of each courtyard was greater with the Qing dynasty layout than with the Song dynasty layout. Furthermore, the Qing dynasty layout reduced the sound field uniformity of the second through fourth courtyards. Changes in bell tower height also significantly affect a temple's interior and exterior sound fields. When the sound source was $3 \mathrm{~m}$ above the ground (i.e., the same height as the wall), both $\mathrm{T}_{30 \mathrm{~m}}$ and $\mathrm{EDT}_{\mathrm{m}}$ reached their maximum values in each courtyard; when the sound source was $6 \mathrm{~m}$ above the ground, $\mathrm{C}_{80}$ reached its maximum values.

(4) With regard to courtyard materials, changes in a courtyard wall's sound absorption coefficient led to significant sound field changes. The simulation showed that for every increase of 0.3 in the sound absorption coefficient, the SPL(A) of the second and third courtyards decreased by 1.2 to $4.0 \mathrm{dBA}$, and the fourth courtyard's SPL(A) decreased by 2.2 to $4.6 \mathrm{dBA}$, causing non-uniform distribution of courtyard SPL(A) and decreasing the $\mathrm{EDT}_{\mathrm{m}}$ and $\mathrm{T}_{30 \mathrm{~m}}$ of each courtyard, while increasing $\mathrm{C}_{80}$, to some extent. However, changes in materials, such as those used in roofs and in windows, did not significantly affect Buddhist temples' courtyard sound fields.

In short, with a bell as the sound source, spatial elements that have significant effects on Buddhist temples' courtyard sound fields include the following: (a) courtyard wall height, (b) position of courtyard partition wall, (c) position and height of bell tower, and (d) the courtyard wall's sound absorption coefficient. Our research indicates that the temple layout of the Qing dynasty (that is, the bell tower with a height of $6 \mathrm{~m}$ located in the first courtyard; the brick courtyard walls with a height of $3 \mathrm{~m}$; and the absence of partition walls between most courtyards), which is adopted by most traditional temples, is beneficial to the spread of the bell sound inside and outside the Chinese Buddhist Temple; therefore, this layout style could be applied to newly built temples. The aforementioned results can, to some extent, elucidate the relationship between the spatial elements of Han Chinese Buddhist temples and courtyard bell sound fields. Moreover, the results may provide support for research on the sound fields of other types of traditional Chinese courtyards.

Author Contributions: Writing-original draft preparation, D.Z.; data curation, C.K.; formal analysis, M.Z.; writing-review and editing, Q.M. All authors have read and agreed to the published version of the manuscript.

Funding: This work was supported by the National Natural Science Foundation of China (grant numbers 51678117 and 51678180).

Conflicts of Interest: The authors declare no conflict of interest.

\section{References}

1. Liu, D. The spatial attributes and basic forms of Chinese traditional courtyards. Lit. Art Stud. 1986, 2, 125-135.

2. Zhang, D.; Zhang, M.; Liu, D.; Kang, J. Sounds and sound preferences in Han Buddhist temples. Build. Environ. 2018, 142, 58-69. [CrossRef]

3. Wang, G. Eastern and Western Architectural Space; Baihua Literature \& Art Publishing House: Tianjin, China, 2006; p. 171.

4. Odah, H.; Ismail, A.; Elhemaly, I.; Anderson, N.; Abbas, A.M.; Shaaban, F. Archaeological exploration using magnetic and GPR methods at the first court of Hatshepsut Temple in Luxor, Egypt. Arab. J. Geosci. 2013, 6, 865-871. [CrossRef]

5. McGovern, S. The Ryoan-ji Zen garden: Textual meanings in topographical form. Vis. Commun. 2004, 3, 344-359. [CrossRef]

6. Davis, M.J.M.; Tenpierik, M.J.; Ramírez, F.R.; Perez, M.E. More than just a Green Facade: The sound absorption properties of a vertical garden with and without plants. Build. Environ. 2017, 116, 64-72. [CrossRef]

7. Hedfors, P. Considering the authenticity of the garden soundscape: Preliminary research based on interviews. Gard. Hist. 2004, 32, 281-284. [CrossRef]

8. Fowler, M. Hearing a shakkei: The semiotics of the audible in a Japanese stroll garden. Semiotica 2013, 197, 101-117. [CrossRef] 
9. Fowler, M. Sound as a considered design parameter in the Japanese garden. Stud. Hist. Gard. Des. Lands. 2015, 35, 312-327. [CrossRef]

10. Wong, N.H.; Tan, A.Y.K.; Tan, P.Y.; Chiang, K.; Wong, N.C. Acoustics evaluation of vertical greenery systems for building walls. Build. Environ. 2010, 45, 411-420. [CrossRef]

11. Gozalo, G.R.; Morillas, J.M.B.; González, D.M.; Moraga, P.A. Relationships among satisfaction, noise perception, and use of urban green spaces. Sci. Total Environ. 2018, 624, 438-450. [CrossRef]

12. Bullen, R.; Fricke, F. Sound propagation through vegetation. J. Sound. Vib. 1982, 80, 11-23. [CrossRef]

13. van der Heijden, L.A.M.; Claessen, V.; de Cock, N. Influence of vegetation on acoustic properties of soils. Oecologia 1983, 56, 226-233. [CrossRef] [PubMed]

14. Londhe, N.; Rao, M.D.; Blough, J.R. Application of the ISO 13472-1 in situ technique for measuring the acoustic absorption coefficient of grass and artificial turf surfaces. Appl. Acoust. 2009, 70, 129-141. [CrossRef]

15. Chourmouziadou, K.; Kang, J. Acoustic evolution of ancient Greek and Roman theatres. Appl. Acoust. 2008, 69, 514-529. [CrossRef]

16. Beranek, L.L.; Hidaka, T. Sound absorption in concert halls by seats, occupied and unoccupied, and by the hall's interior surfaces. J. Acoust. Soc. Am. 1998, 104, 3169-3177. [CrossRef]

17. Vassilantonopoulos, S.L.; Mourjopoulos, J.N. A study of ancient Greek and Roman theater acoustics. Acta Acust. United Acust. 2003, 89, 123-136.

18. Vassilantonopoulos, S.L.; Mourjopoulos, J.M. Virtual acoustic reconstruction of ritual and public spaces of ancient Greece. Acta Acust. United Acust. 2001, 87, 604-609.

19. Farina, A. Acoustic quality of theatres: Correlations between experimental measures and subjective evaluations. Appl. Acoust. 2001, 62, 889-916. [CrossRef]

20. Shtrepi, L.; Astolfi, A.; Puglisi, G.; Masoero, M. Effects of the distance from a diffusive surface on the objective and perceptual evaluation of the sound field in a small simulated variable-acoustics hall. Appl. Sci. 2017, 7, 224. [CrossRef]

21. Bo, E.; Shtrepi, L.; Pelegrín Garcia, D.; Barbato, G.; Aletta, F.; Astolfi, A. The Accuracy of Predicted Acoustical Parameters in Ancient Open-Air Theatres: A Case Study in Syracusae. Appl. Sci. 2018, 8, 1393. [CrossRef]

22. Kamisiński, T. Correction of acoustics in historic opera theatres with the use of Schroeder diffuser. Arch. Acoust. 2012, 37, 349-354. [CrossRef]

23. Martellotta, F.; Cirillo, E. Experimental studies of sound absorption by church pews. Appl. Acoust. 2009, 70, 441-449. [CrossRef]

24. Alonso, A.; Martellotta, F. Room acoustic modelling of textile materials hung freely in space: From the reverberation chamber to ancient churches. J. Build. Perform. Simul. 2016, 9, 469-486. [CrossRef]

25. Berardi, U. Simulation of acoustical parameters in rectangular churches. J. Build. Perform. Simul. 2014, 7 , 1-16. [CrossRef]

26. Berardi, U.; Cirillo, E.; Martellotta, F. A comparative analysis of acoustic energy models for churches. J. Acoust. Soc. Am. 2009, 126, 1838-1849. [CrossRef] [PubMed]

27. Navarro, J.; Sendra, J.J.; Muñoz, S. The Western Latin church as a place for music and preaching: An acoustic assessment. Appl. Acoust. 2009, 70, 781-789. [CrossRef]

28. Cirillo, E.; Martellotta, F. Acoustics of Apulian-Romanesque churches: An experimental survey. Build. Acoust. 2002, 9, 271-288. [CrossRef]

29. de Sant'Ana, D.Q.; Zannin, P.H.T. Acoustic evaluation of a contemporary church based on in situ measurements of reverberation time, definition, and computer-predicted speech transmission index. Build. Environ. 2011, 46, 511-517. [CrossRef]

30. Chu, Y.; Mak, C.M. Early energy decays in two churches in Hong Kong. Appl. Acoust. 2009, 70, 579-587. [CrossRef]

31. Kosała, K.; Engel, Z.W. Assessing the acoustic properties of Roman Catholic churches: A new approach. Appl. Acoust. 2013, 74, 1144-1152. [CrossRef]

32. Brink, M.; Omlin, S.; Müller, C.; Pieren, R.; Basner, M. An event-related analysis of awakening reactions due to nocturnal church bell noise. Sci. Total Environ. 2011, 409, 5210-5220. [CrossRef] [PubMed]

33. Soeta, Y.; Ito, K.; Shimokura, R.; Sato, S.I.; Ohsawa, T.; Ando, Y. Effects of sound source location and direction on acoustic parameters in Japanese churches. J. Acoust. Soc. Am. 2012, 131, 1206. [CrossRef] [PubMed]

34. Girón, S.; Alvarez-Morales, L.; Zamarreno, T. Church acoustics: A state-of-the-art review after several decades of research. J. Sound. Vib. 2017, 411, 378-408. [CrossRef] 
35. Manohare, M.; Dongre, A.; Wahurwagh, A. Acoustic characterization of the Buddhist temple of Deekshabhoomi in Nagpur, India. Build. Acoust. 2017, 24, 193-215. [CrossRef]

36. Orfali, W.; Ahnert, W. Evaluation of existing sound system designs in mosques and alternative modern solutions. J. Acoust. Soc. Am. 2008, 123, 3613. [CrossRef]

37. Clause, L.C. Odeon Room Acoustics Program, version 14. In User Manual; Industrial, Auditorium and Combined Editions: Kgs. Lyngby, Denmark, 2016.

38. Peng, Q.; Fu, R. Computer Accoustic Simulation ODEON Software and its Application. China New Technol. Product. 2010, 172, 44.

39. Yuan, M. Studies on Chinese Contemporary Buddhist Architecture in the Han Area. Ph.D. Thesis, Tsinghua University, Beijing, China, 2008.

40. Hidaka, T.; Beranek, L.L.; Okano, T. Interaural cross-correlation, lateral fraction, and low-And high-Frequency sound levels as measures of acoustical quality in concert halls. J. Acoust. Soc. Am. 1995, 98, 988. [CrossRef]

41. Soeta, Y.; Shimokura, R.; Kim, Y.H.; Ohsawa, T.; Ito, K. Measurement of acoustic characteristics of Japanese Buddhist temples in relation to sound source location and direction. J. Acoust. Soc. Am. 2013, 133, 2699-2710. [CrossRef]

42. Clause, L.C.; George, K.; Juan, G. Odeon Room Acoustics Program, version 13. In User Manual; Industrial, Auditorium and Combined Editions: Kgs. Lyngby, Denmark, 2016; pp. $20-42$.

43. ISO. E. 3382-1. Acoustics-Measurement of Room Acoustic Parameters-Part 1: Performance Spaces; International Standard: Brussels, Belgium, 2009.

44. Okano, T. Judgments of noticeable differences in sound fields of concert halls caused by intensity variations in early re-flections. J. Acoust. Soc. Am. 2002, 111, 217-229. [CrossRef]

45. Zhang, D.; Liu, D.; Kang, J. Soundscape in Han Chinese Buddhist temples. China Archit. Build. Press 2018, 111, 188-197.

46. Cowan, J.P. Architectural Acoustics Design Guide; McGraw-Hill Professional Publishing: New York, NY, USA, 2000.

47. Liu, X. Building Physics, 3rd ed.; China Architecture \& Building Press: Beijing, China, 2011; pp. 506-507.

48. Wu, S. Architectural Acoustics Design Principles; China Architecture \& Building Press: Beijing, China, 2000; pp. 217-219.

49. Horoshenkov, V.K.; Khan, A.; Benkreira, H.; Mandon, A.; Rohr, R. Acoustic properties of green walls with and without vegetation. J. Acoust. Soc. Am. 2011, 130, 2317. [CrossRef]

50. Yang, H.S. Outdoor Noise Control by Natural/Sustainable Materials in Urban Areas. Ph.D. Thesis, University of Sheffield, Sheffield, South Yorkshire, UK, 2013.

(C) 2020 by the authors. Licensee MDPI, Basel, Switzerland. This article is an open access article distributed under the terms and conditions of the Creative Commons Attribution (CC BY) license (http://creativecommons.org/licenses/by/4.0/). 